\title{
Lateglacial and early Holocene vegetation development and fluvial system changes in the northern Meuse valley, the Netherlands: a review of palynological data
}

\author{
W.Z. Hoek ${ }^{1, *}$, E.I. Lammertsma ${ }^{1,2}$, S.J.P. Bohncke ${ }^{3, \dagger}$, J.A.A. Bos ${ }^{4}$, F. Bunnik ${ }^{2}$, C. Kasse ${ }^{3}$, \\ J. Schokker ${ }^{2} \&$ W. Westerhoff ${ }^{2}$
}

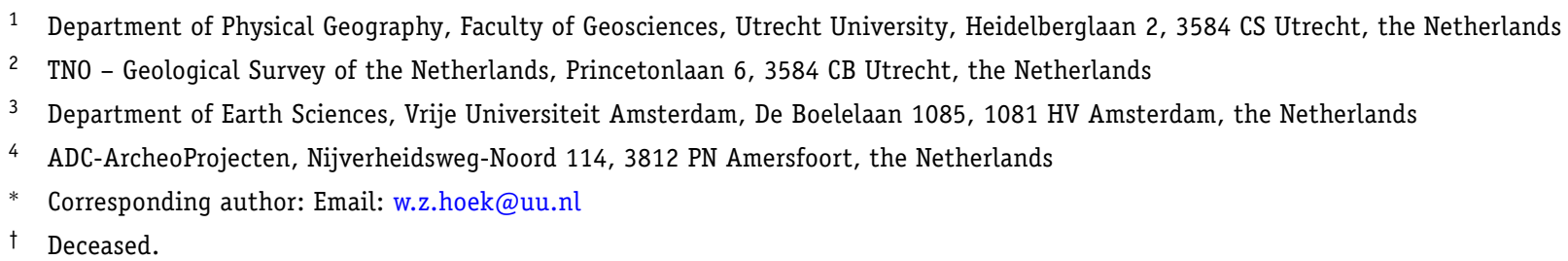

Manuscript received: 14 October 2016, accepted: 14 March 2017

\section{Abstract}

This study provides an overview of existing palynological and chronological data of the northern Meuse valley which have been collected over recent decades. The palynological data were used to make a vegetation reconstruction in time and space for the Lateglacial and early Holocene. The vegetation development is strongly influenced by the rapid climate changes that occurred during this time period. It is shown that the biostratigraphy can be used to provide better age estimates for the abandoned channel fills, which have been dated in most cases using conventional bulk ${ }^{14} \mathrm{C}$ dates. Furthermore, the combination with a geomorphological reconstruction based on AHN (actual height model of the Netherlands) lidar data has been used to evaluate the interactions between fluvial terrace formation and vegetation development. It appears that, although the vegetation development is comparable to the general vegetation development in the Netherlands, slight differences occur, in particular of the vegetation composition, presumably linked to the dynamic geomorphological activity in the Meuse valley. Finally, the spatial distribution of sites may give indications for the migration routes of pine (Pinus) and poplar (Populus) during this period of rapid vegetation development over the Last Glacial-Interglacial Transition.

Keywords: early Holocene, Lateglacial, pollen diagrams, vegetation-landscape interactions, vegetation reconstruction

\section{Introduction}

The Weichselian Lateglacial is characterised by a number of relatively short and rapid climatic changes. It is considered to be the transition period between the cold Pleniglacial and the warm Holocene, and is dated to approximately $12.5-10 \mathrm{ka} \mathrm{BP}$, or 14.7$11.7 \mathrm{ka}$ cal BP (Hoek, 2008). At the start of the Lateglacial the abiotic and biotic environment in the Netherlands reacted to the increasing temperatures, permafrost finally disappeared and the polar desert landscape changed and gradually became vegetated with herbaceous vegetation and birch. Later on, birch and pine forests developed, which stabilised the soils (Hoek, 2001).
Biotic and abiotic landscape interactions occurred between climate, groundwater, sediment supply and soil stability, fluvial activity, and vegetation composition, which continued into the early Holocene. Numerous studies exist on these Lateglacial and early Holocene environmental changes, but these are often site-specific case studies (e.g. local pollen records) or more regional monodisciplinary studies (e.g. geomorphological mapping). Fully integrated studies dealing with vegetation development, fluvial system change and terrace development are scarce to date. Regional changes in vegetation occurred (Hoek, 2000) and the different landscape types responded differently to the climatic changes. A summary of the main changes in Lateglacial 
to early Holocene climate, vegetation and geomorphological changes in the Netherlands is given in Figure 1 (after Hoek \& Bohncke, 2002).

The Meuse valley in northern Limburg experienced distinct geomorphological changes during this climatically dynamic period. This is clearly visible in the Meuse valley south of the hinge point between Venlo and Nijmegen, which is also known as the Sand Meuse due to its generally sandy deposits. Here a series of fluvial terraces has been formed with a maximum elevation difference of c. $8 \mathrm{~m}$, due to stepwise incision and changing fluvial patterns during the Lateglacial to early Holocene period. The palaeochannels associated with the formation of the different terraces are mostly still visible at the surface, which aids geomorphological investigations.

Due to the good preservation of this terrace morphology and the organic nature of the palaeochannel fills, the Sand Meuse valley has been the subject of several studies. Among the first studies in this area were the detailed soil maps made by Pons \& Schelling (1951), Schelling (1951) and Pons (1957) from the Wageningen School, who incorporated geology and geomorphology within their soil mapping. Van den Broek \& Maarleveld (1963) presented a subdivision of the terraces based on elevation and differences in soil development. The study area has been mapped geomorphologically by Buitenhuis \& Wolfert (1988) and Wolfert \& de Lange (1990). More pedogenetic research was performed by Miedema (1988), who showed that Lateglacial terraces are characterised by clay illuviation. In addition, several palynological studies have been performed in this area over recent decades, in order to date and reconstruct the development of the river valley, in some cases supported by radiocarbon dating and with sometimes conflicting results. Detailed palynological research on a number of channel fills in the area was performed by Teunissen $(1983,1990)$ who mainly focused on the dating and reconstruction of the vegetation development in the region around Nijmegen. In the 1990s the Vrije Universiteit (VU) Amsterdam started to work in the Meuse valley in order to investigate the interactions between climate change and fluvial development (Vandenberghe et al., 1994; Kasse et al., 1995), supported by new and integrated palynological studies (e.g. Bohncke et al., 1993). Further downstream, Berendsen et al. (1995) presented a detailed study on buried terrace surfaces in the 'Land van Maas en Waal' region based on $>14,000$ borehole descriptions. Based on sedimentological and palynological data, a renewed subdivision of the terraces was proposed by Kasse et al. (1995), Huisink (1997) and later by van Huissteden \& Kasse (2001). In the meantime, van den Berg (1996) subdivided the terraces based on geomorphology and interpreted their formation based on tectonic movements, while another terrace subdivision has been proposed by Tebbens et al. (1999) based on soil mapping, supported by a large number of radiocarbon dates on channel fill deposits.

Beside these studies, independent palynological research was performed by the Geological Survey and Stiboka (Soil Survey) until the late 1990s in order to date a number of palaeochannels in support of the geological, geomorphological and soil maps. From the above it is clear that a large palynological dataset is available. However, many diagrams and radiocarbon dates have not been published and disagreements on the biostratigraphic interpretation exist, partly because pollen diagrams are not always compared with each other.

For the fluvial terrace discrimination, detailed digital elevation data (AHN (actual height model of the Netherlands) lidar) have become available since the last terrace reconstructions in the late 1990s (see also Cohen et al., 2012; Isarin et al., 2015). With this detailed surface morphology of the terraces, palaeochannels can be identified and fluvial patterns can be reconstructed more objectively. From these recent studies, it became clear that the classic terrace subdivision linked to stadialinterstadial climate changes can be regarded as still valid.

In this study we present an integrated overview of the fluvial terrace and, particularly, vegetation development by combining and comparing all available data in this area. The main objectives of this study are: (1) to present an overview of available pollen diagrams for the Lateglacial-early Holocene; (2) to build a regional Lateglacial-early Holocene vegetation stratigraphy for this region; and (3) to unravel the interactions between climate change, vegetation and fluvial development. It is hypothesised that the incision of the river and terrace formation had a significant impact on the regional vegetation development, and that differences with the general vegetation development for the Netherlands (as defined by Hoek, 1997a) can be identified.

\section{Research area}

The Meuse is a rain-fed river with a catchment of c. $35,000 \mathrm{~km}^{2}$, including parts of France, Belgium, Luxembourg, Germany and the Netherlands. It has a current average discharge of $350 \mathrm{~m}^{3} \mathrm{~s}^{-1}$, with peak values up to $3000 \mathrm{~m}^{3} \mathrm{~s}^{-1}$ (de Wit, 2008). The research area is limited to a section of the Dutch Meuse valley defined by the area from Venlo to the confluence point with the Niers, near Gennep in the north, and the German border in the east to the more elevated coversand area in the west. This area is characterised by a large number of fluvial terraces on which well-preserved palaeochannels are present.

\section{Geological and geomorphological setting}

Originating in northern France, the Meuse flows north through the Paris Basin and cuts through the Belgian Ardennes, from where the bulk of the discharge originates. In its course it cuts through mainly Mesozoic sedimentary rocks in northern France, Palaeozoic and Mesozoic rock in the Ardennes, and Cenozoic unconsolidated sedimentary deposits in the Belgian and Dutch lowlands. North of Maastricht the Meuse enters the Roer Valley Rift System, which is part of the subsiding North Sea Basin. Due to (ongoing) tectonic activity along the southeast edge this area 


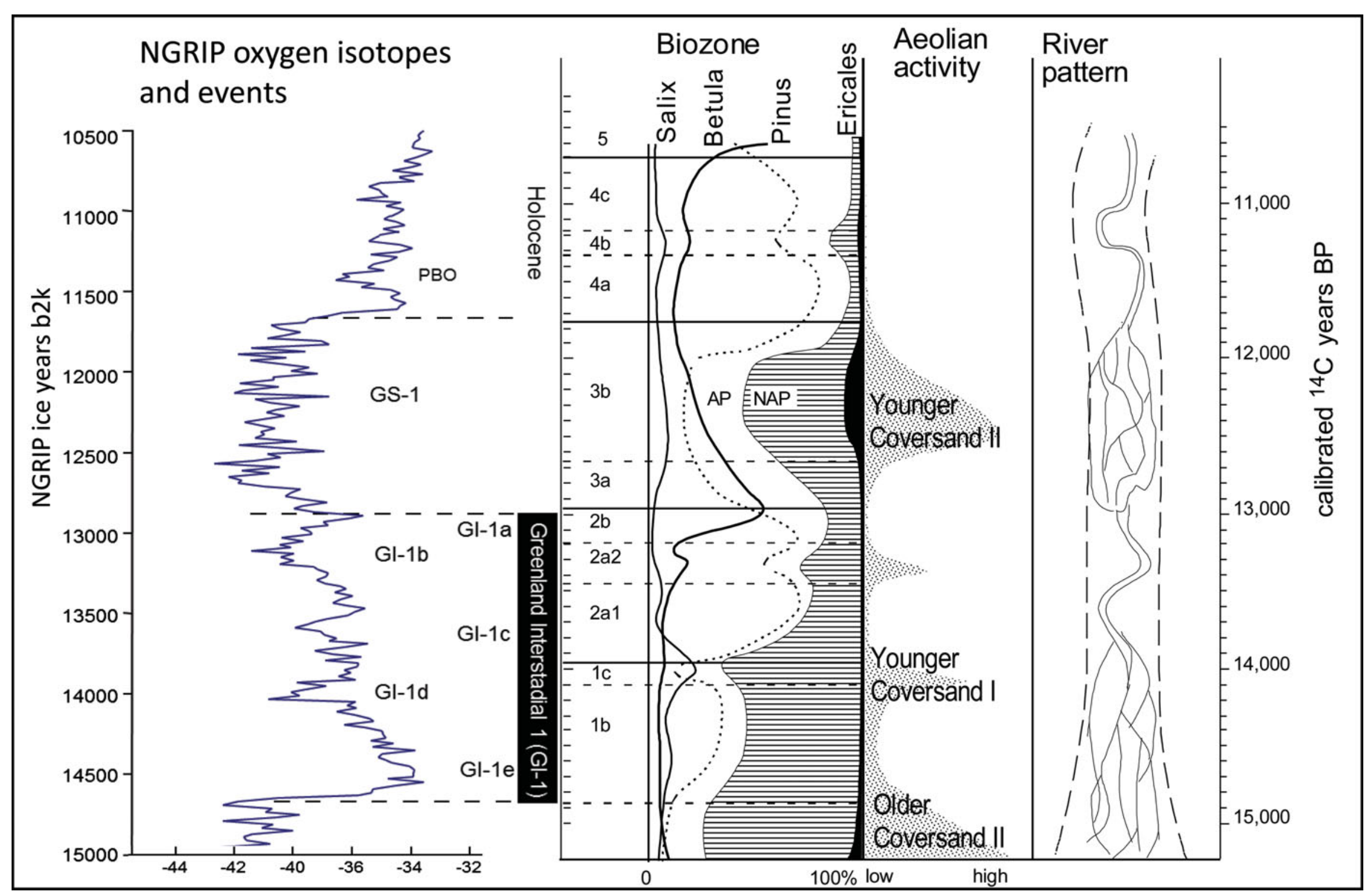




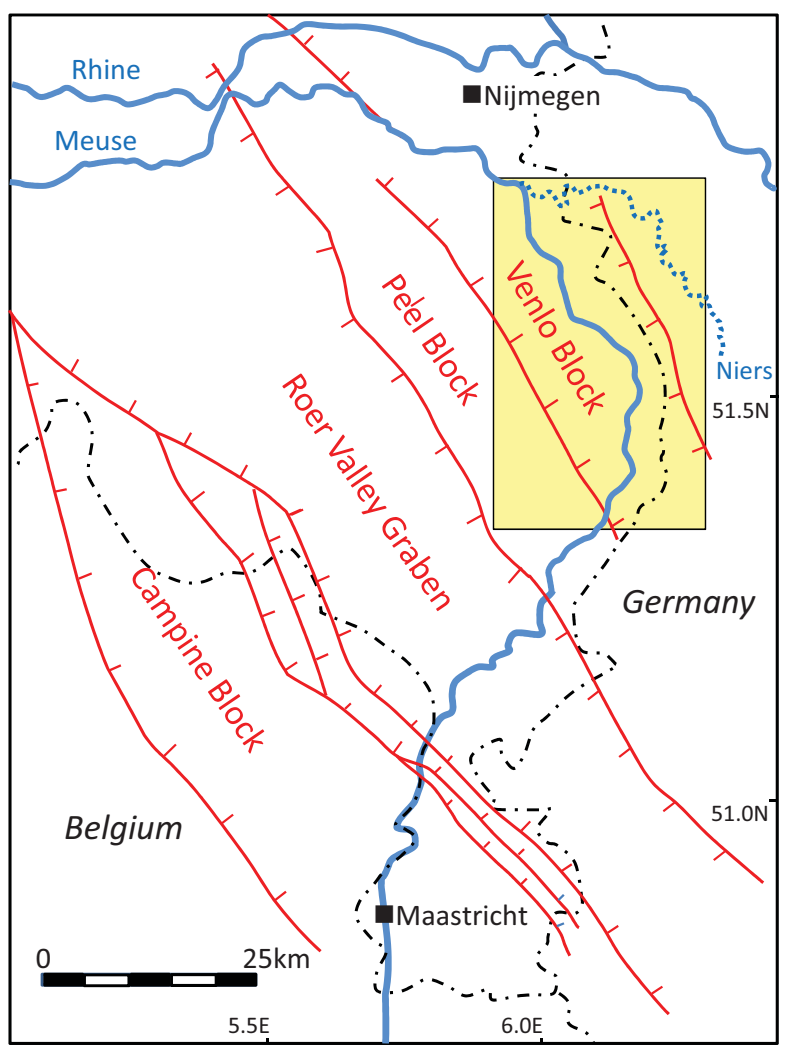

Fig. 2. Geographic and tectonic setting of the Meuse in Limburg, the research area indicated with a yellow box (after van Balen et al., 2000, 2005).

is subdivided into a number of blocks and grabens in between NW-SE-oriented fault lines (Fig. 2). North of the research area indicated in Figure 2, the Meuse joins the river Rhine westward to the North Sea.

The Roer Valley Graben experiences most subsidence and has Quaternary deposits at a depth of $>200 \mathrm{~m}$ (De Mulder et al., 2003). The Peel Block has been strongly uplifted, whereas the Venlo Block takes an intermediate position: rising compared to the Roer Valley Graben but subsiding as compared to the Peel Block. The Rhine, and to a lesser extent the Meuse, occupied the Roer Valley Graben during the middle Pleistocene (Cromerian) and deposited sediments belonging to the Sterksel Formation. Due to a strong uplift of the Rhenish Plateau in Germany during the late Cromerian (400 ka BP), the Rhine altered its course to the north, leaving the Meuse in the Roer Valley Graben to form the Beegden Formation (formerly known as the Veghel Formation; De Mulder et al., 2003). During the Elsterian, Holsteinian and Saalian the Meuse gradually shifted its course over the Peel Horst and onto the lower Venlo Block (Zagwijn \& van Staalduinen, 1975; Westerhoff, 2008).

The (ongoing) tectonic activity is reflected in the fluvial morphology: in the Roer Valley Graben, the Meuse valley is characterised by a broad floodplain and a strong meandering course, while the Meuse appears to have taken the shortest route over the Peel Block where the course is straight and the floodplain narrow. On the Venlo Block, the Meuse changes its direction from northeast to northwest and flows parallel through the Venlo Block, where the floodplain broadens again and the river shows a low-sinuosity course. The research area is located entirely in the Venlo Block, up to the point where due to the fluvial 'hinge line' near Nijmegen the terraces are covered by younger Holocene deposits. The Lateglacial river valley and its terraces in the research area are, therefore, very clearly distinguishable on the digital elevation map (Fig. 3). To the west this section of the Meuse valley is bordered by wind-blown coversands, which mainly formed during the cold and dry Pleniglacial (Schwan, 1988; Kasse et al., 2007). Along the east bank of the Meuse valley, elevated discontinuous parabolic aeolian river dunes are present, which started to form during the Lateglacial Younger Dryas (Pons, 1957; Bohncke et al., 1993; Kasse et al., 1995). Some smaller aeolian river dunes are present on several of the river terraces. Further to the east a number of even more elevated relicts of older Rhine terraces are present.

\section{Methods}

From previous research in the northern Meuse valley, over 35 pollen diagrams and more than 50 radiocarbon dates from before 2008 are available to place the vegetation and geomorphological development in a chronostratigraphical context (Lammertsma, unpublished report, 2008). Several MSc studies have been executed since 2008, which are currently under investigation (H. Woolderink, unpublished data). The amount of existing data has been critically reviewed and put into a stratigraphic framework based on biostratigraphy, and geographically based on the lidar-obtained digital elevation map (AHN). Pollen diagrams are redrawn from the original pollen counts following the method described by Hoek (1997b). Radiocarbon dates are reported as conventional dates BP (Appendix B, available online at dx.doi.org/10.1017/njg.2017.4) . For the analysis, only a small number of accelerator mass spectrometry (AMS) dates on terrestrial macrofossils were available, therefore older radiocarbon dates based on bulk sediment dating have been used, but regarded with caution.

In order to be able to reconstruct past vegetation changes and terrace formation in the Sand Meuse valley, the following steps are taken, using the available palynological and digital elevation data.

First, all pollen diagrams (for which counting data were available) have been revised, rezoned and reinterpreted following Hoek (1997b). The obtained biostratigraphy is correlated to the radiocarbon-dated biostratigraphy of the Netherlands (Hoek, 1997a). Subsequently, the pollen data and radiocarbon dates have been used to date the different terrace sections, of which the borders are defined using the digital elevation data (Fig. 3A). With an age definition of the different terrace sections a palaeogeographical map has been constructed, which 


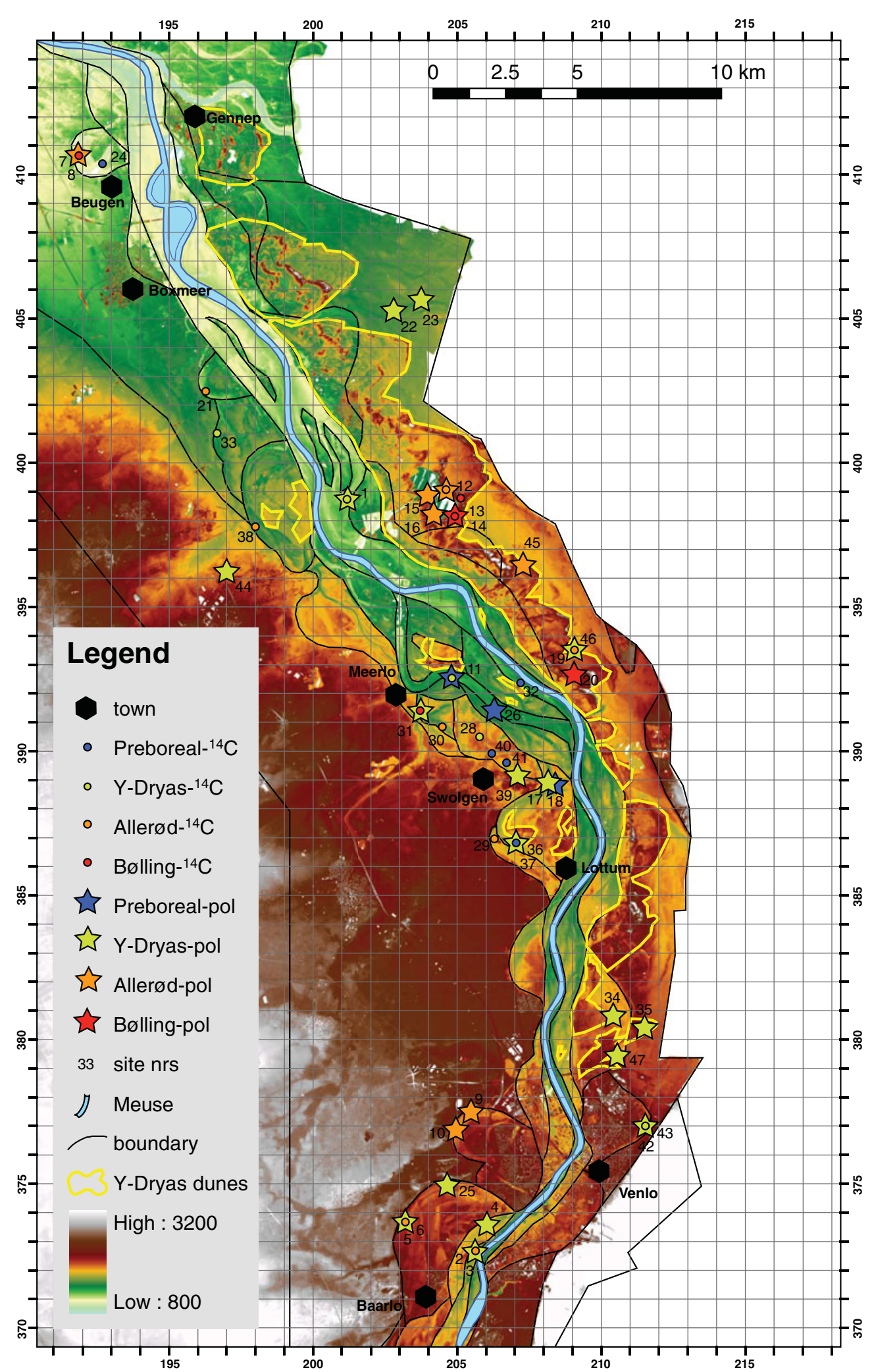

(a)

Fig. 3. (A). Digital elevation map (AHN) of the northern Meuse valley with research sites (see also Appendix A). Elevation indicated by colour scheme in $\mathrm{cm}$ above sea level (high $=32 \mathrm{~m}$ a.s.l. and low $=8 \mathrm{~m}$ a.s.l.). The more elevated river dunes in the landscape are defined by yellow lines. Circle within star indicates pollen and radiocarbon date available at the same sample site. (B) Map of the northern Meuse valley with research sites (see also Appendix A), and terrace subdivision based on the palynological data and radiocarbon dates. Circle within star indicates pollen and radiocarbon date available at the same sample site. The more elevated river dunes in the landscape are indicated as a dotted overlay print. 


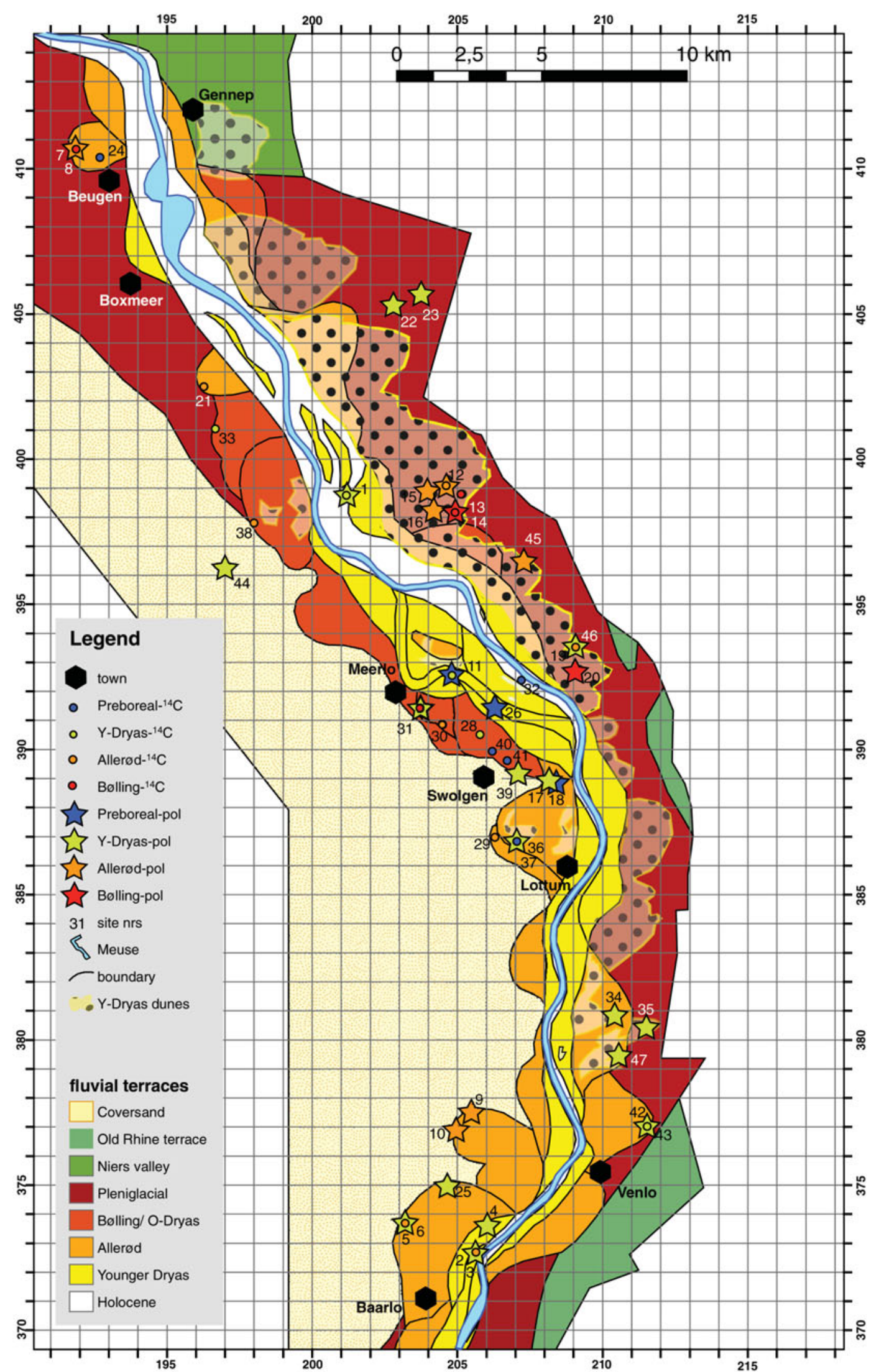

(b)

Fig. 3. Continued 
Table 1. Channel fill ages based on biostratigraphy and ${ }^{14} \mathrm{C}$ dating. (Available pollen and ${ }^{14} \mathrm{C}$ data used in this study are shown in bold.)

\begin{tabular}{|c|c|c|c|c|c|c|c|c|c|}
\hline \multirow{2}{*}{$\begin{array}{l}\text { Pollen diagrams, Institute (ref. no.) } \\
{ }^{a} \text { Well-Aijen, ADC: }\end{array}$} & \multicolumn{8}{|c|}{ recorded bio-zones } & \multirow{2}{*}{$\begin{array}{l}\text { basal date } \\
8845 \pm 35\end{array}$} \\
\hline & & & & & & & & 5 & \\
\hline aOoijen, VU: & & & & & & & & 5 & $9170 \pm 200$ \\
\hline Blitterswijk-Linkstraat, SC (M-11): & & & & & & & 4 & 5 & ${ }^{b} 10,850 \pm 70$ \\
\hline Broekhuizen-Genenberg, SC (M-18): & & & & & & & 4 & & \\
\hline Broekhuizen, VU (M-17): & & & & & & & 4 & 5 & \\
\hline Kasteelweg, VU (M-26): & & & & & & $3 b$ & 4 & 5 & $10,150 \pm 80$ \\
\hline a Baarlo Dubbroek 1990, TNO (M-6): & & & & & & $3 b$ & 4 & & ${ }^{b} 11,830 \pm 180$ \\
\hline Baarlo Klooster De Berckt, SC (M-2): & & & & & & $3 b$ & 4 & 5 & ${ }^{b} 11,460 \pm 80$ \\
\hline Heereven Siebengewald 1, WZ (M-22): & & & & & & $3 b$ & 4 & 5 & \\
\hline Aijen Heuloerbroek, SC (M-1): & & & & & & $3 \mathbf{b}$ & 4 & 5 & $10,600 \pm 60$ \\
\hline Baarlo op den Hert, SC (M-4): & & & & & & 3b & 4 & 5 & \\
\hline Heereven Siebengewald 2, TNO (M-23): & & & & & & $3 \mathbf{b}$ & 4 & 5 & \\
\hline åDe Hamert Heereven, KUN (M19) & & & & & & $3 b$ & 4 & 5 & \\
\hline Schuitwater 2A, VU (M-36): & & & & & & $3 b$ & 4 & 5 & \\
\hline Schandelo I, SC (M-34): & & & & & & $3 b$ & 4 & 5 & \\
\hline Zwartwater, VU (M-47): & & & & & & $3 b$ & 4 & & \\
\hline Venlo-De Koel A, SC (M-42): & & & & & & $3 \mathbf{b}$ & 4 & & \\
\hline Venlo De Koel B, SC (M-43): & & & & & & $3 \mathbf{b}$ & 4 & & $10,660 \pm 60$ \\
\hline${ }^{\mathrm{a} H e l b r o e k, ~ K U N ~(M-24) ~}$ & & & & & & $3 b$ & 4 & & $9920 \pm 190$ \\
\hline Schuitwater 2B, VU (M-37): & & & & & 3 & & 4 & & $10,190 \pm 50$ \\
\hline Hout-Blerick, SC (M-25): & & & & & 3 & & & & \\
\hline Schandelo Ossenberg, TNO (M-35): & & & & & 3 & & & & \\
\hline Baarlo Dubbroek, SC (M-5): & & & & & 3 & & & & \\
\hline Swolgen, SC (M-41): & & & & & 3 & & & & $10,080 \pm 110$ \\
\hline avenray-Boschhuizen, TNO (M-44): & & & & & 3 & & 4 & & \\
\hline${ }^{\mathrm{a}}$ Keuter, VU (M-27) & & & & & 3 & & & & ${ }^{b} 11,780 \pm 270$ \\
\hline Meerlo, VU (M-30): & & & & $3 a$ & & $3 b$ & 4 & 5 & ${ }^{b} 12,500 \pm 120$ \\
\hline âGroeningen-Hultenhoek, VU: & & & $2 b$ & & 3 & & 4 & & $11,280 \pm 80$ \\
\hline${ }^{\mathrm{a} A f f e r d e n-B l e i j e n b e e k, ~ V U}$ & & & $2 b$ & & 3 & & & & \\
\hline Bosscherheide III, VU (M-14): & & & $2 \mathbf{b}$ & & 3 & & & & $11,500 \pm 50$ \\
\hline Bosscherheide IV, VU (M-15): & & & $2 b$ & & 3 & & & & \\
\hline Bosscherheide V, VU (M-16): & & & $2 b$ & $3 a$ & & $3 \mathbf{b}$ & & & \\
\hline Blerick Lake, LPP (M-10): & & $2 a$ & $2 \mathbf{b}$ & & 3 & & & & $11,590 \pm 80$ \\
\hline Wellse Heide, TNO (M-45): & & $2 a$ & $2 b$ & & 3 & & & & \\
\hline Beugen, VU (M-7): & & $2 a$ & $2 b$ & $3 a$ & & 3b & & & ${ }^{b} 12,330 \pm 170$ \\
\hline Blerick-Koelbroek, SC (M-9): & & $2 a$ & $2 \mathbf{b}$ & & 3 & & & & \\
\hline Bosscherheide I, VU (M-13): & 1c & $2 a$ & $2 b$ & $3 a$ & & & & & $12,110 \pm 70$ \\
\hline${ }^{a}$ De Hamert veenlaag, KUN (M-20): & $1 c$ & $2 a$ & $2 b$ & & 3 & & & & $12,210 \pm 70$ \\
\hline
\end{tabular}

aPollen data used indicatively

${ }^{\mathrm{b}}$ Bulk dates related to pollen data, which are regarded as too old due to hard-water/reservoir effect.

basically corresponds to earlier terrace reconstructions (Fig. 3B). With the terrace subdivision defined, the pollen data have been studied in more detail to discriminate between the more local, terrace-related vegetation development and the regional vegetation development. Finally, the differences between this regional vegetation development and the supra-regional development of the Netherlands, and other palaeogeographical reconstructions for this area, are discussed.

\section{Revision of the pollen diagrams}

A total of 47 Lateglacial to early Holocene pollen diagrams are available for the research area. A selection of 28 records for which counting data are available has been used for this study (see Table 1; Appendix A, available online at dx.doi.org/10.1017/njg.2017.4) Other diagrams, for which the pollen counts were not available such as Helbroek (M-24), 
outside the Meuse valley such as Venray-Boschhuizen (M-44), or that are just too young, such as Well-Aijen (Bos \& Zuidhoff, 2015), have been used only indicatively.

The raw counting data were entered in a spreadsheet and, using TILIA (Grimm, 1992-2004), the analysed taxa have been subdivided into palynological groups according to Hoek (1997a). These groups are: trees, shrubs, dwarf shrubs, heath (Ericales), grasses (Poaceae), upland herbs, sedges (Cyperaceae), aquatic taxa, riparian taxa, ferns, mosses, algae, thermophilous trees and Tertiary/reworked taxa. A distinction between trees and thermophilous trees is made, because taxa included in the latter group (like Corylus, Alnus and Tilia) are known to be absent during the period under investigation and, if present, are most probably reworked from older deposits in the catchment.

The pollen diagrams are presented up to the point where the values for especially hazel (Corylus) and alder (Alnus) start to dominate over pine (Pinus). This occurs during the early Holocene, when these taxa migrated from their refugia elsewhere in Europe and the increase indicates the start of the Boreal, respectively Atlantic Period (Hoek, 1997a), which are outside the scope of the present study. In most cases there is a natural stagnation of organic accumulation or even a hiatus at the transition from the Preboreal into the Boreal, presumably linked to drier conditions (Hoek 1997a; Bos \& van Geel, 2017).

For all samples relative values for the taxa are calculated respective to the pollen sum. Vegetation groups included in the pollen sum are trees, (dwarf) shrubs, heath, grasses and upland herbs, which generally grow at some distance from the sampling site. These regional species are assumed to reflect a climate-induced vegetation development. Local and extra-local species in the aquatic and riparian groups, including sedges, ferns, mosses and algae groups, reflect hydroseral changes in the local environment of the sampling site. They do not reflect regional vegetation and are excluded from the pollen sum as these species were actually growing on the sampling sites. Also excluded from the pollen sum are the thermophilous tree species and old/reworked taxa.

Main indicator taxa birch (Betula), pine (Pinus), willow (Salix), upland herbs and heath (Ericales) are displayed together in a main diagram. The curves of the other taxa are exaggerated by $5 \%$ to make small changes better visible. In all diagrams the pollen sum is given for each spectrum.

A graphical description of the lithology for the sample cores (where available) is given with the pollen diagram. This gives additional information on the conditions present at the time of deposition, and has been used to support the interpretation of the palynological data.

\section{Construction of Meuse biostratigraphy and chronostratigraphy}

First, for each revised pollen diagram the pollen spectra are subdivided into Pollen Assemblage Zones (PAZs) based on changes of the taxa in the main diagram along with other indicator taxa.

For the construction of a generalised regional vegetation development we selected six pollen diagrams (Fig. 4). The selected diagrams are composed of a relatively large number of spectra with a significantly high pollen count, encompassing at least three zones, located at some distance from each other, and comprise a lithological description. Based on the similarities between the vegetation changes recorded in the selected Meuse pollen diagrams and the radiocarbon-dated PAZs of the Netherlands (Hoek, 1997a) a correlation was made. In this study, uncalibrated ${ }^{14} \mathrm{C}$ ages BP are used for the correlations.

The correlation of the PAZ with the Netherlands chronostratigraphy is further supported by the available radiocarbon dates. This chronostratigraphy has subsequently been applied to the other northern Meuse pollen diagrams.

\section{Definition of the terrace sections}

The lidar elevation data of the defined research area have been processed in ArcGIS and positioned on the standard Dutch grid system, the 'Rijksdriehoekstelsel'. By choosing a multi-colour scheme and setting the maximum value to $32 \mathrm{~m}+$ NAP (Dutch ordnance datum) and the minimum value to $8 \mathrm{~m}+\mathrm{NAP}$, maximum differentiation is given in the elevation differences of the terraces. In this way, areas with higher (aeolian river dunes and coversand area) and lower values (more downstream areas) are generalised. Elevation values of lakes and the Meuse itself are regarded as unreliable due to the differential reflection of water surfaces, and are not considered absolutely.

Contour lines are drawn along clear and continuing elevation differences in the landscape. This is done with the editordrawing tool in an ArcGIS lines shapefile. In areas where the fluvial patterns were unclear, the local relief was optimised by changing the range of the $\mathrm{min} / \max$ values in the colour scheme. In most cases, channels themselves are not indicated by contour lines, because they are part of the fluvial plain they are situated on.

The different lines are then merged to form a 'polyline', which subdivides the elevation map into a large number of 'fluvial sections'. However, no distinction between the various terraces is made yet, and multiple sections may be present on a similar elevation level.

\section{Reconstruction of the palaeogeographical development}

The available ages of the base of palynological records and radiocarbon dates have been sub-divided into four main periods: Bølling/Older Dryas, Allerød, Younger Dryas and (early) Holocene. The precise ages as upper and lower boundaries of these periods or biozones follow the definitions by Hoek (1997a) for the Netherlands (Table 2). 


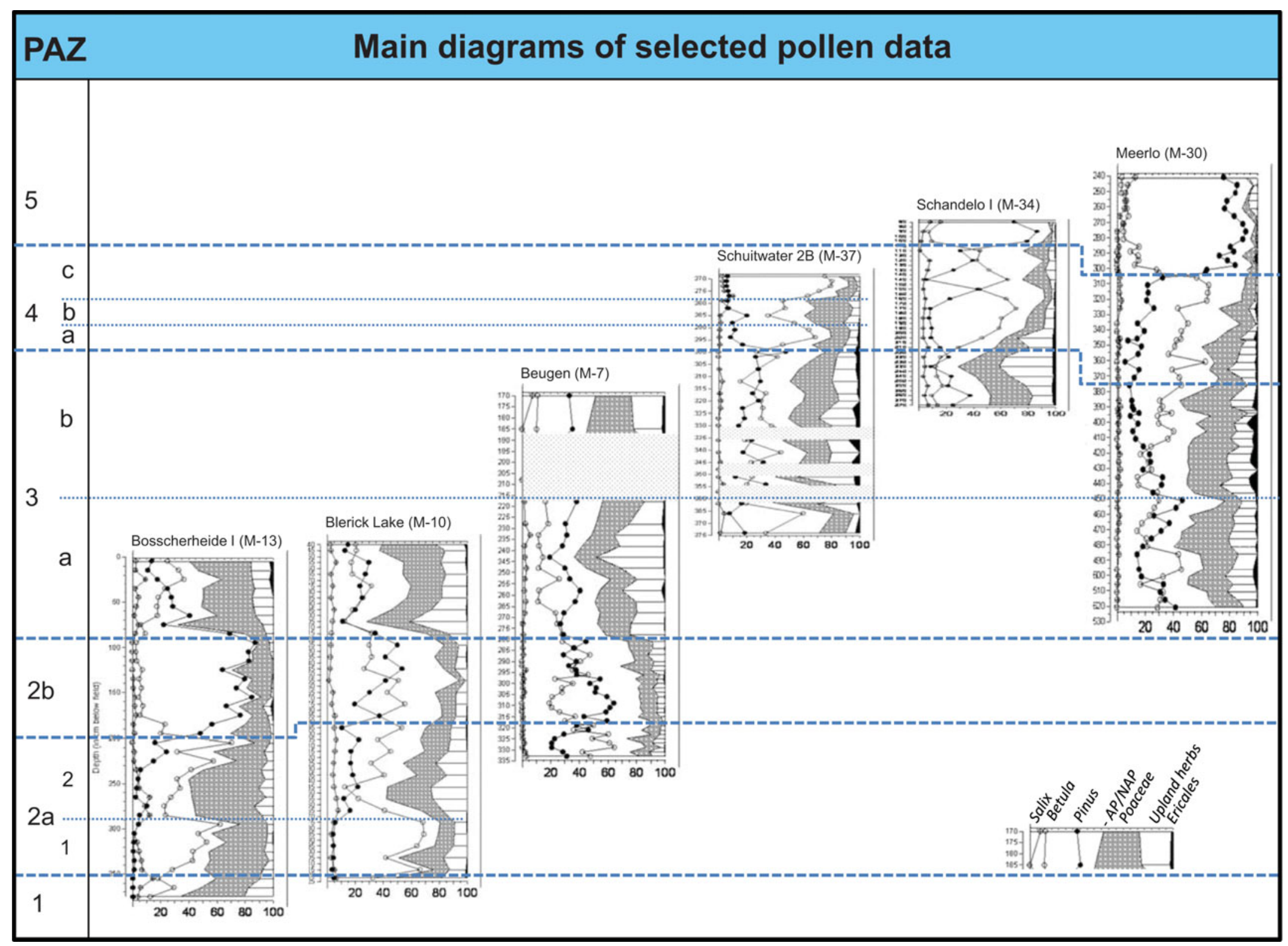


Table 2. Comparison of Meuse PAZ and radiocarbon dates to chronostratigraphy (Hoek, 1997a) and biostratigraphy (van Geel et al., 1981, 1989) as defined for the Netherlands. Number in brackets after the Meuse radiocarbon date refers to the research site from which it originates (see also Appendix B).

\begin{tabular}{|c|c|c|c|c|}
\hline Meuse PAZ & $\begin{array}{l}\text { Radiocarbon dates Meuse valley } \\
\text { (diagram numbers) }\end{array}$ & $\begin{array}{l}\text { PAZ Netherlands } \\
\text { (Hoek, 1997a) }\end{array}$ & $\begin{array}{l}\text { Radiocarbon-dated zone } \\
\text { boundaries (Hoek, 1997a) }\end{array}$ & $\begin{array}{l}\text { Biozones (van Geel et al., } \\
\text { 1981; 1989; Hoek, 1997a) }\end{array}$ \\
\hline \multirow[t]{4}{*}{5} & & 5 & & Late Preboreal \\
\hline & & & 9500 & \\
\hline & \multirow[t]{2}{*}{$9600 \pm 40(1)$} & $4 c$ & & Early Late Preboreal \\
\hline & & & 9750 & \\
\hline \multirow[t]{5}{*}{4} & \multirow[t]{3}{*}{$9705 \pm 55(36)$} & $4 \mathrm{~b}$ & & Rammelbeek Phase \\
\hline & & & 9950 & \\
\hline & & $4 a$ & & Friesland Phase \\
\hline & $10,150 \pm 80(80)$ & & 10,150 & \\
\hline & & $3 b$ & & \\
\hline \multirow[t]{4}{*}{3} & $10,600 \pm 60(1), 10,660 \pm 60(43)$ & & 10,550 & Younger Dryas \\
\hline & & $3 a$ & & \\
\hline & & & 10,950 & \\
\hline & $10,870 \pm 100(20), 10,940 \pm 60(13)$ & & & \\
\hline \multirow[t]{3}{*}{$2 b$} & & $2 b$ & & Allerød Pine Phase \\
\hline & & & 11,250 & \\
\hline & $11,170 \pm 80(11)$ & & & \\
\hline \multirow[t]{2}{*}{$2 \mathrm{a}$} & $11,300 \pm 60(13), 11,465 \pm 50(20)$ & $2 \mathrm{a}$ & & Allerød Birch Phase \\
\hline & & & 11,900 & \\
\hline 1 & $12,110 \pm 70(13), 12,160 \pm 65(20)$ & $1 \mathrm{c}$ & & Older Dryas \\
\hline
\end{tabular}

The periods and dates are transferred into eight separate tables and uploaded onto the digital elevation data in ArcGIS. The different periods are indicated by four different colours, while the palynological and radiocarbon dates are differentiated through two symbols, respectively a star and a circle (Fig. 3). For a number of sections, multiple dates are available, which in some cases contradict each other. A more detailed analysis of the most reliable dates is given below.

After the provisional age estimation of the separate fluvial sections, a comparison of the morphology and relative elevation is made between sections of the same age estimation. Here also discrepancies may occur: for two sites with the same age estimation but at different elevation levels, it is assumed that the age of the lower site more closely matches the real age, while the age of the higher site is considered too young. Also in these cases a more detailed analysis is performed to determine which date is most reliable and why.

When the dates for the various fluvial sections are defined, this information is extrapolated to the other (undated) sections. This is done by comparing the fluvial morphology, lithology (if possible) and general elevation of the sections, so that for each section an age estimation is given.

For the uppermost fluvial plain, no radiocarbon dates and pollen diagrams are available. Based on Kasse et al. (2007), a
Pleniglacial age is applied in this research following the studies cited above. All sections that are defined as having been formed during the same period are given the same colour fill in the map. In this way the interpretation of the spread of the various Lateglacial to early Holocene terraces is provided in the shape of a map.

\section{Reconstruction of the regional vegetation development}

Based on changes in patterns and values of indicator species that are present in the pollen diagrams (Betula, Pinus, Salix, Juniperus, Ericales, Poaceae and a selection of upland taxa), a generalised regional vegetation development is described below. Available radiocarbon dates in selected diagrams are used to give an approximate age for the regional vegetation development following Hoek (1997a). A selection of pollen diagrams is presented that has not previously been published, and this selection provides a sequence over the Lateglacial and early Holocene that is characteristic for the northern Meuse valley in N Limburg (Fig. 4). This compilation diagram can be used for future biostratigraphic correlation in the region.

For comparison of the vegetation development on the various terraces, pollen diagrams with a high resolution and containing 
multiple zones are selected for each terrace (at least two, maximum six). No data were available for the Pleniglacial plain.

The general pattern of each PAZ of the different terraces is described and significant differences are discussed. Changes in the extra-regional species are used to recognise reactivation of the palaeochannels, together with an increased minerogenic input in the deposits.

\section{Results}

\section{Pollen Assemblage Zones (PAZs)}

Simultaneous changes in the composition of plant and tree species at different locations are thought to reflect regional vegetation development. Based on similar changes of indicator taxa in six high-resolution diagrams (Fig. 4; complete diagrams in Appendix $C$, available online at dx.doi.org/10.1017/njg.2017.4), all available pollen diagrams are, if possible, subdivided into five regional Pollen Assemblage Zones. The values of the presence of the main indicator taxa (i.e. Betula, Pinus, Salix, Juniperus, Ericales, Poaceae, various upland herbs, and arboreal pollen/non-arboreal pollen (AP/NAP)) within each PAZ, and the changes by which the upper limit is defined, are described below.

PAZ 1: Betula-Juniperus PAZ At this point the AP is low ( $\pm 40 \%$ ) and consists of mainly Betula (30\%), besides Pinus and Salix. The NAP component is approximately two-thirds composed of Poaceae and one-third of other upland herbs. A large variety of heliophilous taxa are present, such as Helianthemum, Plantago and Artemisia (5-10\%), together with indifferent types such as Galium, Apiaceae and Thalictrum which are assumed to have been growing in the region's vegetation. Towards the end of the zone, Juniperus and Salix increase to peak values of $15-20 \%$. The transition to the next PAZ is defined by a strong increase of Betula.

PAZ 2a: Betula PAZ In this PAZ, Betula is the main component, with an average value of $60-80 \%$, while Pinus values remain low (5-20\%), and Juniperus and Salix almost disappear. The variety of upland herbs from the previous zone is still present, albeit in lower amounts (especially Artemisia which decreases to $<5 \%$ ) related to the strong increase in AP. Helianthemum remains present at the start of this zone, whereas Plantago seems to disappear after the start. After the initial expansion of $B e-$ tula, a temporary decrease in its presence occurs, simultaneously with an expansion of mainly Poaceae and to a lesser extent upland herbs like Artemisia, Asteraceae Tubuliflorae, Galium and Apiaceae. While Betula decreases, the first gradual expansion of Pinus occurs, after which both expand again later on. The end of this zone is defined as where Pinus percentages are equal to or larger than Betula percentages.
PAZ 2b: Pinus-Betula PAZ In this PAZ, Pinus starts to dominate the vegetation composition, with values ranging from $>20 \%$ to $80 \%$, while values for Betula and the NAP are strongly diminished as compared to the previous zones, related to the increase of Pinus. The variety and values of (upland) herbs are significantly decreased, most noticeably those of Artemisia, Asteraceae Tubuliflorae, Sanguisorba officinalis, Galium and Thalictrum, while others maintain but do not exceed previous values. The end of this zone is indicated by a sudden and strong decrease in Pinus values and AP in general, in favour of upland herbs and Poaceae.

PAZ 3: Poaceae-Ericales PAZ This zone is characterised by high NAP values, representing an increase in both upland herbs and Poaceae. Betula and Pinus are present with, on average, similar values, in the range $10-40 \%$. Salix expands as compared to the previous zone, to an average of $2 \%$, and occasionally higher. The total NAP value reaches c. 50\%, with Poaceae as the main component. The presence and variety of upland herbs increases considerably compared to the previous zone. Heliophilous upland herbaceous species that expand most noticeably during this zone are Artemisia (up to 10\%), Papaver rhoeas, Valerianellatype, Helianthemum, Plantago, Chenopodiaceae and both Asteraceae Liguliflorae/Tubuliflorae. Regular occurrence of Dryas and Ephedra is characteristic of this zone. Ericales, particularly Empetrum, expand up to $5 \%$ during the latter part of this zone. Juniperus is present throughout this zone, but peaks towards the end, where the increase of Betula indicates the transition to the next zone.

PAZ 4: Betula-Poaceae PAZ The gradual increase of Betula is accompanied by an increased presence of Juniperus (up to $5 \%$ ), which disappears when Betula reaches its maximum of $60-80 \%$. Other trees like Salix and Pinus remain below 10\%. Most heliophilous taxa like Helianthemum, Empetrum and Polygonum bistorta type generally disappear, while Artemisia and Asteraceae Liguliflorae decrease strongly. Poaceae are lower than before but remain at a general 10-20\%. A brief drop in Betula values occurs, sometimes coincident with an increase of Poaceae or Pinus, after which Betula resumes its previous values until it is outcompeted by Pinus. Often Populus is also found in this zone, mostly towards the end. The new zone is defined where Pinus starts to increase and eventually dominates over Betula.

$P A Z$ 5: Pinus $P A Z$ Following the previous dominance of Betula, values of Pinus increase up to $90 \%$. Upland herbs decrease sharply or disappear, and NAP values average c. 5-10\%. The only herb still occasionally found is Artemisia. The end of this zone is determined by an increase of Corylus and/or Alnus to values larger than $5 \%$.

When comparing the vegetation development for the Meuse valley with the key changes during the Lateglacial to early Holocene of the Netherlands given by Hoek (1997a), strong similarities are found. In this way a correlation of the PAZ for the 
Meuse valley and biozones as described for the Netherlands is possible (Table 2).

Recording of the vegetation development in the palaeomeanders started in the Older Dryas. This period is characterised by a fairly open landscape of grasses and heliophilous herbs with scattered birch and juniper trees and shrubs. Since this period is thought to be dry rather than cold (van Geel \& Kolstrup, 1978; Bohncke, 1993), the high values of willow most probably represent an upland species. Following this period, shrubs and herbs disappear and a birch forest develops, representing the Allerød birch phase. Within the Allerød birch phase, a transient opening of the birch forest occurs, facilitating the development of a more steppe-like landscape, coinciding with zone 2a2 (Fig. 1). Afterwards the birch forest re-establishes and is gradually mixed in with pine, up to the point where pine takes over. This is identified as the Allerød Pine phase. Apparently, the developing pine forest grew dense enough to create unfavourable conditions for a large number of (heliophilous) herbs, which generally disappear from the landscape until the sudden reopening of the landscape at the start of the Younger Dryas. In this cooler period a wide variety of heliophilous herbs is present, together with (dwarf) birch, heath and juniper shrubs in an open steppe-like landscape. The end of this zone is defined by the reoccupation of birch in the open grassland, preceded by a short expansion of juniper shrubs. This has generally been described for the start of the Preboreal (= Friesland Phase). A dense and homogeneous birch forest then develops and the light-demanding herbs disappear again. Finally, the birch forest changes to a dense and homogeneous pine forest, indicating the last phase of the Preboreal. The end of this zone is defined by hazel or alder becoming dominant over pine, indicating the start of the Boreal or Atlantic, respectively.

\section{Description of the digital elevation map}

Figure $3 \mathrm{a}$ shows the height differences that occur over short distances in the area near the current Meuse, which represent the various sections of the fluvial terraces. To the west the uniform high area is part of the aeolian coversand region. East of the Meuse valley three smaller areas with high elevations are present, which are relicts of older Rhine terraces that extend across the border with Germany. Elevated parabolic landforms with a SW-NE orientation occur along the east bank of the Meuse. These are aeolian river dunes topping several terraces with an extra $10-15 \mathrm{~m}$ of sand. Focusing on the Meuse valley, a general elevation decrease occurs from $24 \mathrm{~m}+$ NAP near Baarlo in the south to $13 \mathrm{~m}$ near Gennep in the north for the uppermost fluvial plain, and from 17 to $10 \mathrm{~m}+$ NAP for the lowest plain. Over a distance of $c .50 \mathrm{~km}$ this equals a general gradient of $0.22 \mathrm{~cm} \mathrm{~km}^{-1}$ and $0.14 \mathrm{~cm} \mathrm{~km}^{-1}$, respectively. This also implies that an elevation difference of up to $7 \mathrm{~m}$ is present between the highest and lowest fluvial plain in the southern part and $3 \mathrm{~m}$ in the northern part of the research area. The width of the Meuse valley increases downstream, and north of Gennep it merges with the Niers valley.

Based on differences in elevation and morphology, the research area is subdivided into a large number of fluvial sections or levels. Each section is thought to represent a different phase in the fluvial development, even though some neighbouring sections occur at approximately the same elevation. The spread and size of the sections are not homogeneous over the research area. Along the outer edge of the fluvial terraces large meanders are present in the southern part between Baarlo and Lottum, nested against the more elevated coversand region along the west bank (Fig. 3b). On some of these large meanders, small 'channels' cutting over the pointbars are present (swales), beside the main channel along the outer edge. Further north where the current Meuse changes its course to the northwest, these large meanders disappear and a complex of smaller but multiple highsinuosity channels is present near Meerlo-Swolgen. These meanders are dissected by lower sections closer to the current Meuse east of Meerlo (Blitterswijck). These can be described as elongated plains with bars, and in some cases multiple channels are present at the surface. In the northern part of the research area near Boxmeer-Beugen the terrace sections are fewer, and consist mainly of an increasingly broad plain in which the current Meuse is present. Within the lowest plain a number of elongated 'islands' are present (Fig. 3b).

\section{Palaeogeographical development of the Meuse terraces}

Information concerning the geomorphological development has been obtained from the detailed elevation map (Fig. 3a). Because of the general incising trend, higher sections represent older fluvial development stages. Cross-cutting relations of fluvial sections emphasise the order of formation, which is used where elevation is not sufficiently discriminating. Surface morphology present on the fluvial plains gives an indication of the size and pattern of the fluvial system forming that section. It is assumed that channel shape and size do not differ greatly during the same time interval. Earlier research revealed that the aeolian river dune complexes were formed during the Younger Dryas period, indicating that the underlying fluvial plains must be older (Bohncke et al., 1993).

The numbers mentioned behind the names in the text correspond to pollen sites or radiocarbon-dated sites, listed in Appendix $\mathrm{A}$, and are indicated on the elevation and terrace maps (Fig. 3a, b).

Pleniglacial No pollen diagrams are available for this level. However, according to previous research, during the Late Pleniglacial the Meuse had a braiding aggrading pattern that was present from the older Rhine terraces in the east to the west (Bohncke et al., 1993; Kasse et al., 1995). The western part of this fluvial plain was covered by aeolian deposits, indicated in the map as 
coversand area (Kasse et al., 2007). Multiple narrow and slightly curving channels are recognisable in the surface morphology of this most elevated fluvial plain, especially in the more downstream part near Boxmeer and west of Beugen (Fig. 3a). From the presence of large-scale cryoturbations and ice-wedge casts found in this plain it is deduced that permafrost conditions prevailed during this period (Kasse et al., 2007), and the channels were likely to be dry during winter. Due to the low vegetation cover and the aeolian input, the sediment load of the Meuse was high, and together with spring peak floods the surface morphology was frequently reshaped. Organic material from one of the channels indicated that this system was abandoned at the start of the Bølling (Bohncke et al., 1993), which is supported by an AMS date of $12,390 \pm 100$ on Betula and Salix remains (Huisink, 1999).

Bølling/Older Dryas Two pollen sites, Bosscherheide I (M-13) and de Hamert-veenlaag (M-20), east of the Meuse clearly show a relatively high level of upland herbs and Juniperus, indicative for the Older Dryas, before the Allerød Betula expansion. Radiocarbon dates at these sites confirm this palynological age estimate (see Table 1). This indicates that the fluvial plain from which these samples were taken was abandoned before the Older Dryas, during the Bølling. Unfortunately, the fluvial morphology of these sites is obscured by the overlying aeolian river-dune complex. In the centre of the research area, between Swolgen and Meerlo, a complex of narrow channels is preserved, locally with a high-sinuosity pattern, nested against the coversand region (Fig. 3). In many of these channels, radiocarbon dates have been determined, with ages ranging from the early Allerød to the end of the Preboreal (Table 1). These dates are probably too young, when the data of lower-lying sites are considered. Therefore, the Bølling to Older Dryas age of these sections is based on the elevation as compared to the other fluvial plains. From the above, it can be deduced that during the Bølling the braiding pattern changed into a more sinuous, perhaps multichannel system (Kasse et al., 1995; Huisink, 1997). At the start of the Weichselian Lateglacial, climate conditions became warmer, and winter temperatures especially increased strongly. As a result, vegetation was able to settle again and soils stabilised, decreasing the sediment influx into rivers. This lower sediment load together with a decreasing peak flow resulted in the concentration of the river flow. In the Meuse valley most channels of the braiding fluvial system were abandoned during the Bølling, while some incised and gradually developed a higher sinuosity. Since no strong elevation difference between the Pleniglacial and Bølling floodplain exists, the younger plain is distinguished by the shape and size of the channels.

Allerød Following the Older Dryas period, climate conditions changed and the landscape became densely vegetated, which is apparent from the low NAP percentages in this zone. The change to a high-sinuosity fluvial system, which started dur- ing the previous period continued with a strong incision of $\pm 5 \mathrm{~m}$ into the Pleniglacial/Bølling fluvial plain, especially in the south. However, the shape and size of the meanders dated to the Allerød are not uniform, ranging from relatively small to much larger ones that appear to have migrated downstream. Two clear and well-dated examples of the first are meander Beugen (M-7, M-8, M-24) in the north and meander Blerick (M-9, $\mathrm{M}-10$ ) in the south. The infill of meander Beugen shows a transition from gyttja at the base to (sandy) clay, palynologically assigned to respectively the Allerød Betula and Pinus phase (PAZ $2 \mathrm{a} / 2 \mathrm{~b}$ ) and the Younger Dryas (PAZ 3). This infill points to a neck cut-off abandonment of the meander at the start of the Allerød, after which at the transition to the Younger Dryas the palaeomeander was regularly inundated (Kasse et al., 1995). A radiocarbon date of calcareous gyttja of Bølling age at this site is probably too old, because of the hard-water effect related to bulk dating of gyttja. Furthermore, the elevation and the morphology of the meander are different from the previously discussed Bølling fluvial plain. A bulk date of Preboreal age $(9920 \pm 190 \mathrm{BP})$ obtained from the Allerød-Younger Dryas transition in pollen diagram Helbroek (M-24) is considered too young, probably related to the presence of roots. In meander Blerick both pollen diagrams, Blerick Koelbroek (M-9) and Blerick Lake (M-10), show a meander fill from the Allerød Betula phase up, as in Beugen (Fig. 4). An AMS date from the basal infill of Blerick Lake (M-10) yielded 11,590 $\pm 80 \mathrm{BP}$, which confirms an early Allerød age. It appears that early in the Allerød the Meuse had a high-sinuosity course and neck cut-offs occurred. Both meanders have a difference in height of over $6 \mathrm{~m}$ between the top of the pointbar and the channel lag, which gives an indication of bank-full channel depth. In some sites, such as Bosscherheide I (M-13) and Blerick Lake (M-10), the relatively closed birch forest becomes more open during the second part of the Allerød Betula phase, perhaps indicating an increased flooding frequency or a temporarily colder phase (Hoek 1997a).

The fluvial pattern gradually changed later in the Allerød, and is especially well represented in the southern part of the research area. From Baarlo to Lottum, large meander scars are present, with swales cutting over the pointbars (Fig. 3). Their more elongated shape as compared to the Beugen and Blerick meanders suggests a lower sinuosity and downstream migration. Palynological data from these meanders indicate a Younger Dryas base of the infilling, often found in sandy or clayey gyttjas (e.g. Baarlo-Dubbroek: M-5; Schuitwater 2B: M-37). In some pollen diagrams (e.g. Schuitwater 2A: M-36), the transition to the early Preboreal (Betula increase) is also recorded, and the clastic input in the deposits disappears at this time. The start of the infill indicates that these meanders were abandoned during the Younger Dryas and thus were active during the Allerød. Radiocarbon dates taken from pollen sites Venlo de Koel B (M-43) and Schuitwater (M-36, M-37) match the palynological age, while bulk radiocarbon dates of early Allerød age at Baarlo Dubbroek 1990 (M-6) and Lottum (M-29) appear too old. An optically 
stimulated luminescence (OSL) date from the pointbar deposits in this plain near Lottum yielded $12.4 \pm 0.6 \mathrm{ka}$, confirming a late Allerød age (Zuidhoff \& Huizer, 2015). From the above it is concluded that at the start of the Allerød the discharge was regular enough for a high-sinuosity, single-channel meandering system to develop. The first meanders probably evolved from the former Bølling meanders, enlarging and widening them. Later in the Allerød, sinuosity seems to decrease and the meanders show more downstream migration. A significant elevation difference is present between the older and younger Allerød meanders, indicating that lateral migration and incision was a continuous process during the Allerød.

Younger Dryas and early Preboreal At the start of the Younger Dryas, the Meuse started to incise but also inundated the Allerød meanders during increased peak (spring) floods, depositing clastic material at several sites (e.g. Bosscherheide, Beugen) (Kasse, 1995). In the course of the Younger Dryas, the Meuse incised (c. $4 \mathrm{~m}$ ) into the Allerød floodplain and changed to a low-sinuosity channel pattern (Fig. 3b). The surface morphology on most of the Younger Dryas sections shows bars and swales, and locally a multichannel system can be recognised east of Meerlo (Blitterswijck). Allerød meanders became abandoned by chute cut-off as new channels were formed over previous pointbar surfaces (Kasse, 1995). Clear examples of chute cut-offs of Allerød meanders by the Younger Dryas system are present near Lottum and Baarlo. The pollen data in the Baarlo meander fill (M-5, M6, M25) show a more or less complete Younger Dryas interval, while two pollen sites (M-2 and M-4) in the lower plain contain a record of the end of the Younger Dryas and the Preboreal. This indicates that this lower plain was abandoned shortly before the end of the Younger Dryas. A radiocarbon date at Baarlo Klooster de Berckt (M-3), however, points to an Allerød age, which is likely to be too old because of the hard-water effect related to bulk gyttja dating.

A number of river sections along the east bank of the valley eroded the western border of aeolian river dunes, indicating that they were active at the time the dunes were formed during the Younger Dryas. This is confirmed by site Aijen Heuloerbroek (M1), where a Younger Dryas age is found in the basal clastic infill of a channel. The transition to the Preboreal is characterised by a change to more organic deposits. Other pollen diagrams available for the Younger Dryas floodplain are Blitterswijk Linkstraat (M-11) and Kasteelweg (M-26). Both diagrams have low AP values at the base due to high percentages of Poaceae, but the presence of Populus points to a Preboreal rather than Younger Dryas age for the abandonment of the channels. Both samples are taken from a wide channel, incised into other Younger Dryas sections (Fig. 3). It is therefore suggested that at the start of the Preboreal period, river flow concentrated in a single-channel system. Climate cooling at the start of the Younger Dryas period and the occurrence of discontinuous permafrost limiting the infiltration capacity of the soil resulted in increased spring peak flows. Even though vegetation cover was reduced, trees still occupied parts of the landscape, stabilising the soil. Due to this combination of large flows and relatively low sediment supply, the Meuse incised and changed to a low-sinuosity (multichannel) system. The different elevations of the Younger Dryas fluvial sections suggest a continuous incision during this period.

Holocene During the early Holocene the Meuse further incised into the Younger Dryas/early Preboreal floodplain, and meander migration strongly decreased. The Holocene floodplain is practically absent in the south while it increases in width to the north, covering the Younger Dryas floodplain, and there are several channels with an early Holocene fill (e.g. Aijen Heuloerbroek: M-1; Blitterswijk-Linkstraat: M-11, 0oijen, Well-Aijen). The Haelen record (Bos et al., 2007; Bos \& van Geel, 2017) compares well with other pollen diagrams of the northern and middle Meuse river valley. The distinction between the early Preboreal fluvial section and the current Holocene floodplain is difficult to make, based on elevation. According to Miedema (1988), however, soils with a clay illuviation horizon (Argillic-B horizon of Luvisols) are characteristic for the Lateglacial to early Holocene floodplains while they are absent on the current Holocene floodplain. The Holocene vegetation development and fluvial evolution are outside the scope of this study and the reader is referred to Zuidhoff \& Bos (2017), Bos \& van Geel (2017) and other contributions in this issue.

\section{Lateglacial and early Holocene vegetation development on the different terraces}

Besides rapid climate changes, the studied section of the Meuse valley has experienced large geomorphological changes during the Lateglacial, caused by fluvial pattern changes and incision creating the fluvial terraces. It is hypothesised that this resulted in an unequal vegetation development on the different terraces at the same moment in time. The palynological records obtained from the various terraces reflect the vegetation changes that occurred after the terrace was abandoned, due to the incision of the system and the formation of a new terrace. Below, differences are described for each Lateglacial terrace, and a synthesis of the regional vegetation composition during the terrace formation in the research area is given in Figure $5 \mathrm{a}-\mathrm{f}$.

Pleniglacial plain (Fig. 5a) During the Pleniglacial, the Meuse had a braided pattern with swiftly changing bars and shallow channels. There are no palynological indications for the presence of a vegetation cover, which was supposedly scarce due to the fluvial activity in the braided river plain. On the higher bars herbaceous vegetation could possibly develop which stabilised the surface. It is likely that several channels were active at the same time, while aeolian and periglacial processes also occurred. Apart from a bulk date on selected twigs from Bosscherheide (Tebbens et al., 1999; Appendix B), there is little evidence for the presence of local vegetation during this period. 
Bølling/Older Dryas plain (Fig. 5b) During the first part of the Lateglacial, when temperatures rose, the river Meuse started to deepen its channels and changed to a more sinuous multichannel meandering system. In some of the channels, which were abandoned during this phase, organic loam was deposited with some palynological and macrofossil evidence, which shows that shrubs like willow, juniper and dwarf birch were present in the herbaceous vegetation, while the first birch trees supposedly grew on the abandoned braid bars.

Early Allerød plain (Fig. 5c) The surface morphology of the meanders of this terrace is characterised by a single channel and a high and large pointbar. The vegetation development on the uppermost fluvial plain starts to be recorded in abandoned channel fills while meanders were cut-off as soon as the channels continued to deepen. In the cut-off channel fills, relatively high values of Betula indicate that relatively dense birch forests were present on the abandoned older river plains, which were enriched with the first deposition of loam. The lower section of the pointbars presumably facilitated the various open upland herb taxa recorded in the pollen diagrams, as compared to the older and more elevated plains, throughout the Allerød period. The elevation of the higher pointbars is comparable to the Pleniglacial and Bølling/Older Dryas plains, and it is expected that the vegetation development here is similar.

Late Allerød plain (Fig. 5d) During the second part of the Allerød, meandering continued and the river Meuse deeply incised, leading to the formation of terraces on both sides of the river. Generally, higher values of pine during PAZ-2b are found in the channels bordering the higher plains, indicating that dense forests comprising birch and pine were present on the oldest plains. After the incision of the fluvial system during the Allerød, these terraces remained relatively undisturbed, allowing dense pine forests to develop. On the early Allerød pointbars, birch remained the most important tree species, while the lower pointbar plains were likely covered with a rich herbaceous vegetation with grasses and shrubs capturing flood loam.

Younger Dryas plain (Fig. 5e) The change to a colder climate with more irregular discharge led to the formation of an incised multichannel braid plain during the first part of the Younger Dryas, where lower temperatures considerably influenced the vegetation. In the second part of the Younger Dryas, sand was blown out of the braid plain, which could be caught in the still available vegetation on the east bank of the Meuse, resulting in the formation of large river dunes. Palynological data from the large-scale meanders that are abandoned during the later part of the Allerød have a Younger Dryas infill at the base. The Younger Dryas vegetation on this terrace differs from that of the older terraces in the locally higher presence of herbaceous pollen and willow. The small differences in surface elevation of the low pointbars with swales, the nutrient-rich loamy sediments and the relatively high water table in the beginning of the Younger Dryas formed a suitable habitat for willow to settle. Also, slightly higher values of Ericales are found in the eastern meander bends of this terrace, as compared to the earlier Allerød terrace. It is most likely that these higher values are the result of heath expansion on the more elevated Pleniglacial plain (where aeolian river dunes were developing at this time) and that heathland pollen was transported over the more open landscape, onto the lower terrace.

Early Holocene plain (Fig. 5f) The onset of the Holocene is characterised by abrupt and distinct changes in vegetation and discharge leading to renewed deepening of the channels. The incision during the early Holocene resulted in the formation of the lowest terrace plain, which consists of the former braided river deposits of Younger Dryas age. Within this incised valley, the Meuse followed a low-sinuosity course and frequently inundated the slightly higher Younger Dryas plain. The clearest difference in vegetation composition of this lowest terrace compared to higher levels is the strong presence of grasses (of over $50 \%$ ). Generally, the vegetation during the early Preboreal period consists of high values of birch, which supposedly grew on the higher terraces, with local presence of pine on the drier, sandy parts consisting of coversand and river dunes. The situation is supposed to be comparable to that in the Scheldt valley (Bos et al., 2005), where locally high values of grasses are indicative of this period. It is possible that the recorded Poaceae pollen is derived from Phragmites, and that at the start of the Holocene the Younger Dryas terrace was covered with reed vegetation. However, there are no macroscopic indications in the lithology that reed was present, and it is therefore concluded that the Poaceae represent an open grassland community.

\section{Discussion}

For this research a large palynological dataset was made available, making it possible to reveal regional trends in the northern Meuse area and developments compared to the general vegetation development for the Netherlands (Hoek, 1997a). The data from the sites were gathered by various companies or institutions over a period of more than 40 years, analysed by different people and used for different purposes, such as biostratigraphic dating or vegetation reconstruction. This has resulted in datasets with differences in detail (amount of pollen counted), resolution (number of pollen samples in a sequence), and level of determination (number of pollen types). For example, pollen of tree-birch (Betula pubescens/pendula, one of the main components of Lateglacial vegetation) and of the shrub Betula nana are not always separated from each other, because the pollen grains are very similar. Unfortunately, the environmental preferences for these species are very different, resulting in a loss of information in the dataset. Similarly, 

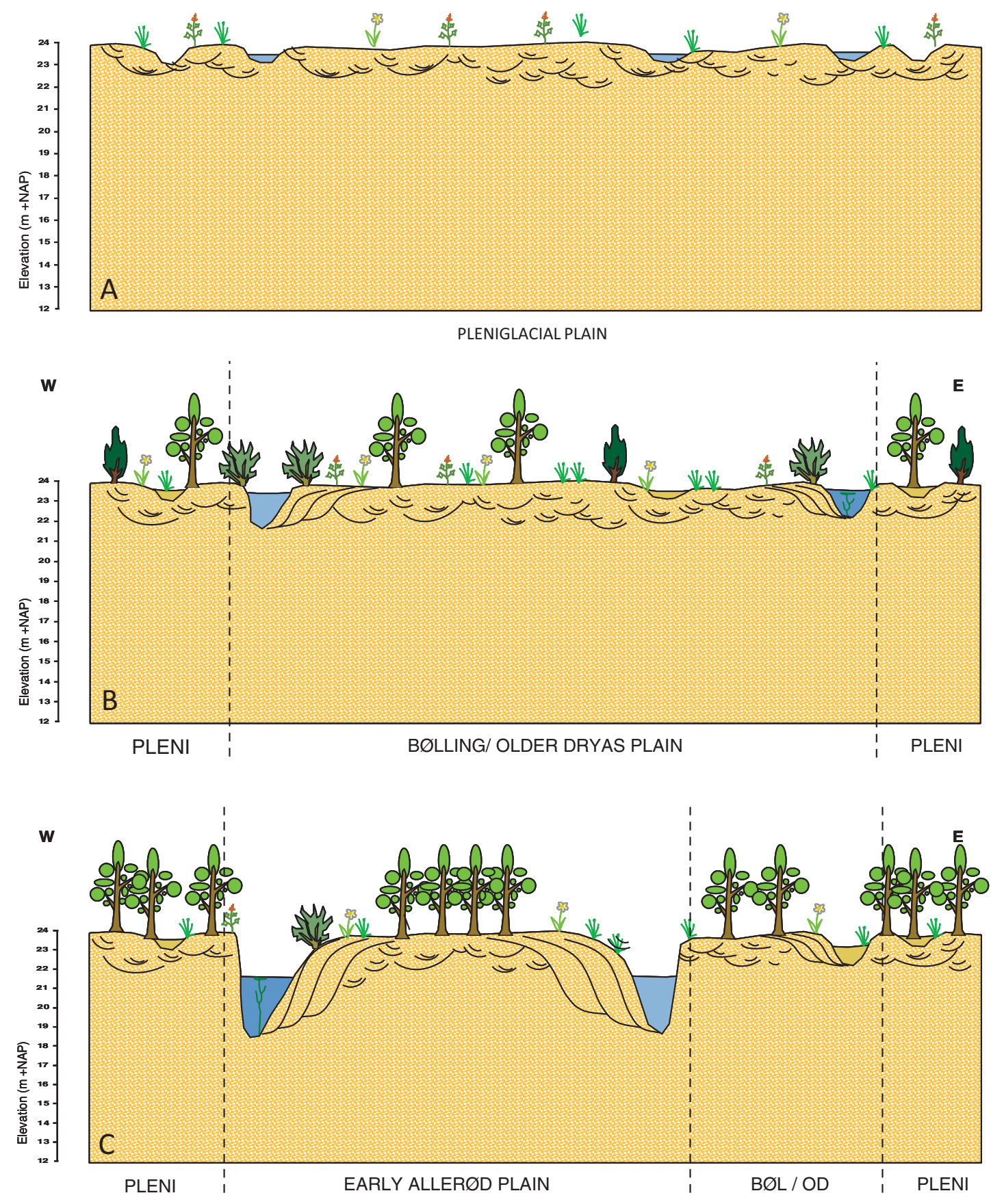

Fig. 5. Vegetation reconstruction for the Meuse valley during sequential time periods of terrace formation. (A)Pleniglacial, scarcely vegetated with predominantly herbaceous taxa. (B) Older Dryas, park landscape with some birch, juniper and willow, and herbaceous taxa. (C) Early Allerød, predominantly dense birch forest. (D) Late Allerød, predominantly dense pine and birch forest, with herbaceous taxa on the valley floor. (E) Younger Dryas, predominantly open landscape with herbaceous taxa, some trees and juniper and heath shrubs. Aeolian river dunes are formed on the eastern terraces, during the later part of this period. (F) Early Holocene, birch forest, with herbaceous taxa (mostly grass) occurring on the lower floodplains.

pollen of Juniperus is not always recognised, particularly in the older datasets. Because of this, the comparison of the different datasets in order to detect differences between the terraces or with the general vegetation development in the Netherlands is not always straightforward. However, the amount of data from a relatively small research area makes it possible to correlate the diagrams to each other based on the general vegetation development in the region (see Fig. 4). 

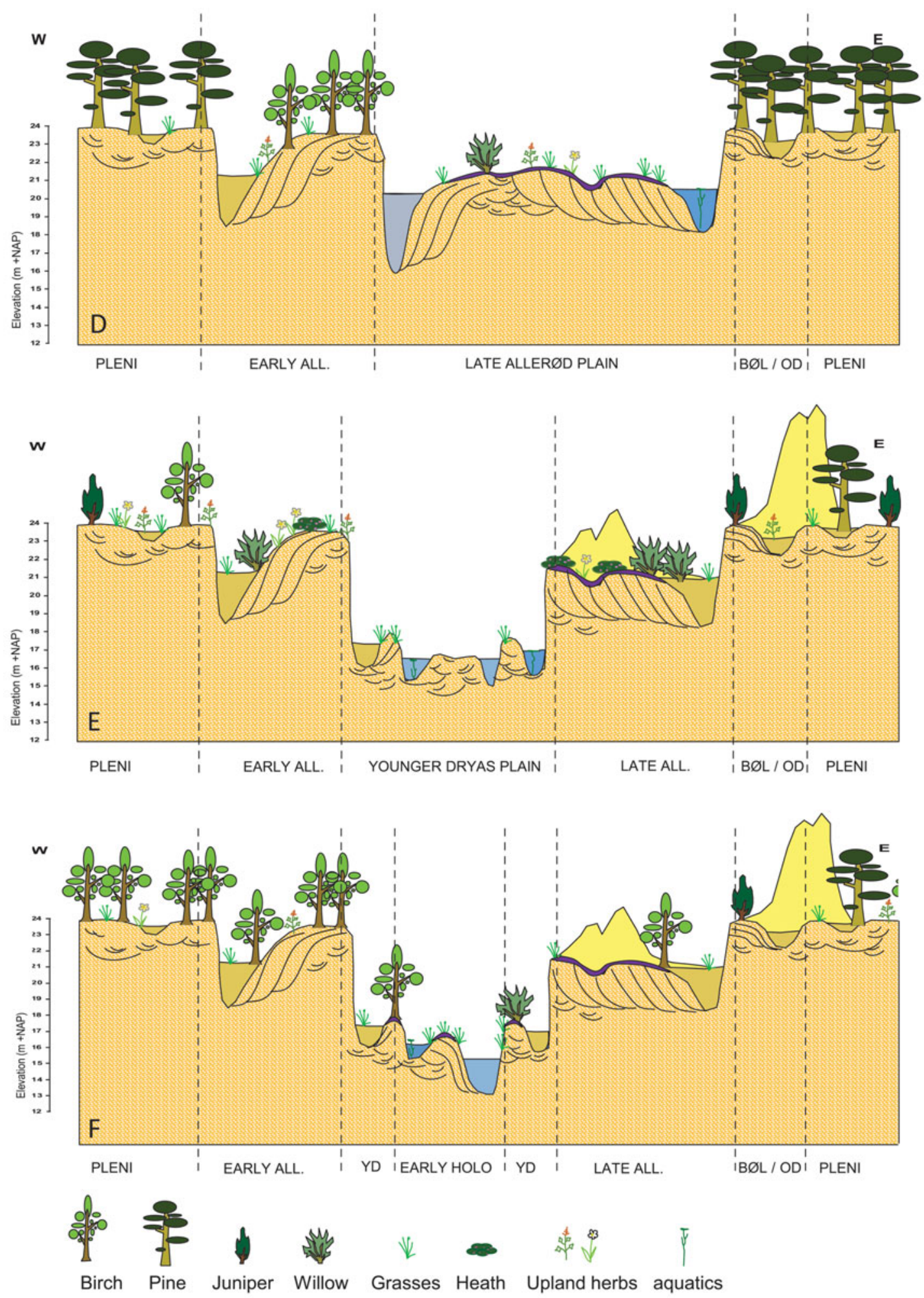
Sandy substratum
Aeolian dune
Active channel
Overbank silts
Channel fill
Abandoned channel

Fig. 5. Continued 
Another factor that might bias the interpretations is the presence of reworked taxa in most of the diagrams. These originate from older deposits upstream and are often found in clastic channel-fill sediments. Some of the reworked taxa have not existed in northwest Europe for millions of years (e.g. Classopollis, Nyssa, Pinus haploxilon) and are easily separated from the contemporaneous taxa. The fact, however, that they are present in the pollen record does indicate that long-distance fluvial transport of pollen grains occurred and that other taxa that are common in this period were not necessarily growing at the investigated sites. A good example is Pinus, the pollen grain of which, with its air bladders, has a very long flotation time, which is, in addition to the very efficient wind transport of Pinus pollen, the reason why a presence of over $20 \%$ is, according to Huntley \& Birks (1983), indicative of actual local growth. It is assumed, however, that the level of long-distance fluvial transport was not high enough to obscure the general Lateglacial vegetation patterns.

For some terraces, palynological data are only sparsely available in the research area. For example, the vegetation development on the Pleniglacial plain is based on diagrams from a few sites on the east bank of the Meuse. Since the more elevated coversand area is on the western bank, it seems plausible that vegetation development here was different from the vegetation development on the eastern bank. This means that the vegetation reconstruction of the Pleniglacial terrace is only valid for the plain on the east bank. Therefore, it should be kept in mind that the presented results on vegetation composition might be biased. Nevertheless, the differences between the terraces show a pattern with more pioneer herbs on a recently abandoned floodplain and denser forest on a higher stable terrace, so the results are considered reliable.

\section{Comparison with the general vegetation development in the Netherlands}

When the regional vegetation development of the Meuse valley is compared to the generalised vegetation diagram of the Netherlands, similar patterns are obvious (compare Figs 1, 4 and Table 2). Some differences occur:

1. The values for Ericales in the northern Meuse valley are often lower than those recorded for the rest of the Netherlands. The high values composed for the Netherlands originate mostly from sites in the till regions (Hoek, 2000), where the poorly drained substratum, in combination with leached and nutrient-poor soils, provides suitable growing conditions for Ericales, also because there is little competition. The northern Meuse valley provided these conditions probably on older terrace deposits, since the Meuse terraces are better drained and consist of nutrient-rich fluvial sand and loam, which, together with more competition of trees, resulted in a generally lower presence of Ericales.
2. It has been thought that Pinus migrated into the Netherlands via the Rhine corridor, because the highest values of this tree during the Allerød Pine phase were found at sites located in the Rhine valley in the Netherlands and Germany (Hoek, 2000; Bos, 2001). In the northern Meuse valley, the highest values of Pinus are found on the Pleniglacial plain east of the Meuse (sites from Bosscherheide M-13, M-14, M-15, M-16). Values for Pinus in, for example, Beugen (M-7) and Blerick Lake (M-10) in the western part of the Meuse valley are $c$. $20 \%$ lower. It is possible that the pine forest developed east of the Meuse, perhaps entering the area via the Niers-Rhine that was still active at that time, confirming the 'Rhine as corridor' theory (Kasse et al., 2005).

3. No general subdivision for the early Preboreal is possible in the northern Meuse valley, because only occasionally (e.g. in Schuitwater 2B: M-37) has a distinct Rammelbeek phase grass expansion been found. A decrease in Betula is found in almost all diagrams; however, it occurs together with a premature expansion of Pinus rather than Poaceae (e.g. in Schandelo I: M-34; Venlo-de Koel B: M-43). At the Haelen site (Bos et al., 2007; Bos \& van Geel, 2017), in the middle Meuse river valley, however, a clear distinction can be made between the Friesland and Rammelbeek phases, while further south, at the site Kingbeekdal, clear opening phases in the birch forest also occur during the early Preboreal (Bohncke \& Hoek, 2007). Also, the limited increase of Populus in the last part of the Preboreal Birch phase (zone 4c) is not always recorded in the northern Meuse valley. When Populus is found, it is often present throughout the Preboreal Birch phase. At Haelen (Bos et al., 2007; Bos \& van Geel, 2017) and Kingbeekdal (Bohncke \& Hoek, 2007), Populus is also present from the start of the Preboreal onwards. Hoek (1997a) stated that the first part of the Preboreal (the Friesland phase) is often absent due to a hiatus, which might explain the absence of Populus. In the northern Meuse valley diagrams, no proof for this assumption is found and it is therefore thought that Populus migrated into the area soon after the birch expansion. During the Late Preboreal, the pine values increase. This occurs earlier in the records of the downstream part of the middle Meuse river valley (Bos \& van Geel, 2017) and may suggest that the terraces of the Meuse river valley formed a migration route for pine during the early Holocene.

\section{Comparison with the vegetation development in the coversand region west of the river Meuse}

The Meuse vegetation development for the Lateglacial to early Holocene period is specific to this river valley, although the general trend is shown to be similar to that of the Netherlands (Tables 1, 2). To test to what point the dynamic river valley development has played a role in the vegetation history and not just its geographical location, the northern Meuse valley is compared to a nearby site close to the northern Meuse val- 
ley, i.e. Milheeze (Bos, unpublished report, 1992; Bos, 1998; Bos et al., 2006). This site is a former lake located west of Venray on the coversand area of Noord Brabant. The coversand region has an undulating topography and is composed of thick layers of aeolian quartz-rich sands deposited mainly during the Pleniglacial (Schwan, 1988). When Milheeze is taken as representative for the (eastern) coversand region, the vegetation development of the northern Meuse river valley and Milheeze can be compared and dissimilarities are likely the result of differences in geomorphology, drainage and lithology. The Milheeze area experienced different geomorphological changes during the Lateglacial period: except for periods with aeolian sand transport, the area is fairly stable. This in turn influences the way the vegetation could develop. When comparing the general developments, the following main similarities and differences can be summarised. For the Older Dryas period a similar vegetation composition is described for the northern Meuse valley and the site near Milheeze. Here also an open herbaceous landscape, with mainly shrubs of willow and juniper and scattered birch trees, was present. In the following Allerød Birch phase, the value of Betula pollen expands to a similar level in both Milheeze and the northern Meuse river valley. Based on the concentration of NAP pollen, the presence of remaining heliophilous herbs must indicate that the birch forest was still open, at least on the coversand ridge (Bos, 1998; Bos et al., 2006). The expansion of grasses in the northern Meuse valley during the Allerød birch phase is not recorded near Milheeze, whereas the expansion of pine at this point is found at both sites. Moreover, the local presence of pine is confirmed by macro-remains found on the coversand ridge near Milheeze. During the Allerød Pine phase, the value for pine was highest on the coversand ridge. This is similar to the high values found on the Pleniglacial and Bølling/Older Dryas terraces in the northern Meuse valley, where the drier and sandy conditions of these localities are the preferred growing spot for pine. The pine forest on the coversand ridge, however, seemed more open, with herbaceous undergrowth, than in the northern Meuse valley, where almost no upland herbs are present during this period. Also near Milheeze, heath could develop on the coversand ridges in the undergrowth of the open pine forest, unlike the Meuse valley. The denser forest vegetation in the northern Meuse valley might be related to the more nutrient-rich sandy and loamy soils on the terraces in comparison to the coversand area. During the Younger Dryas a similar open birch-pine forest was present at both sites. In the western coversand area of the Netherlands, the late Allerød pine forest was more open and facilitated more herbaceous taxa and heath, which were practically absent in the Meuse valley pine forest, especially on the topmost terraces. At Milheeze the Younger Dryas could be divided into two phases of increased opening of the pine-birch forest (Bos, 1998; Bos et al., 2006). Moreover, on the coversands, pine disappeared during the second phase of the Younger Dryas, to be replaced by open vegetation with shrubs and heather taxa. A similar trend is recorded in the northern Meuse valley, although pine remained present especially on the uppermost (eastern) terraces.

Hoek (1997b) defines the river valleys as a different landscape unit, because of its dynamic nature during the Lateglacial, related to climate changes. Based on the fluvial evidence presented in the introduction above, it is clear that the northern Meuse valley was very sensitive to the climate changes that occurred over northwestern Europe. The dynamic river valley setting with localised geomorphic instability and strong gradients in hydrology, lithology and nutrient availability has caused the more subtle changes in vegetation development. This is apparent in, for instance, the locally more open character of the vegetation during the early Allerød and Preboreal, with a clear decrease in birch values.

\section{Conclusions}

Based on a review of palynological and radiocarbon data in the northern Meuse area, the Older Dryas to (early) Holocene vegetation development of this region has been reconstructed from a large number of channel fill deposits. The major trends in vegetation development are similar to the general development in the Netherlands in timing and composition. The earliest phase of the Lateglacial is not represented in the northern Meuse valley due to the dynamic nature of the fluvial landscape. The fluvial activity led to reoccupation of channels and the lack of archives. Only when the Meuse started to incise, and the channel pattern changed from braided to meandering, could abandoned channels start to record the vegetation development in this region. After the open park landscape of the Older Dryas, the borders of the northern Meuse river valley became densely forested with birch in the early Allerød and with pine in the late Allerød. After this the landscape reopened during the Younger Dryas, and open herbaceous and some heath vegetation was common between scattered trees. Due to the climate amelioration in the early Holocene, birch forest again developed, later followed by pine.

The fluvial systems changes have been reconstructed based on morphological analyses (AHN lidar) and palynological and radiocarbon data which provided age estimates for channel abandonment. Fluvial incision and terrace formation is thought to have occurred during the early and late Allerød $(\sim 5 \mathrm{~m})$ by a sinuous meandering system; during the Younger Dryas $(\sim 4 \mathrm{~m})$, when it changed to a low-sinuosity pattern; and finally during the early Holocene $(\sim 2 \mathrm{~m})$, when the Meuse concentrated into the single low-sinuosity channel of today.

The subtle differences in vegetation development compared to the general vegetation development of the Netherlands and between the terraces are caused by the dynamic river valley landscape. For example, willow and herbs are more abundant on the recently abandoned loamy floodplains, while trees are found on the more elevated terraces with stable and nutrient-rich soil conditions. 
The higher presence of taxa that prefer active aeolian sand deposition (like juniper and heath), which generally occurred during the Younger Dryas in the Netherlands, is not clearly evident in the data, although a slight increase may be linked to the river dune formation during the second part of the Younger Dryas.

In the early Preboreal, high values of Poaceae are found in the abandoned channel fills, which, it is suggested, represent the development of an open grassland community on this lowlying plain.

Correlation of the Meuse pollen zones to the general Lateglacial zonation for the Netherlands shows that, although differences in percentage values of certain taxa such as juniper or heath exist, there is no clear lead or lag in the vegetation development of the northern Meuse river valley as compared to the rest of the Netherlands.

\section{Acknowledgements}

This paper is dedicated to the memory of Sjoerd Bohncke, who unexpectedly passed away the day after we submitted the manuscript for review. Sjoerd has worked on many of the Lateglacial and early Holocene sites in the Meuse valley presented in this study. Sjoerd was particularly enthusiastic about Bosscherheide: 'a Lateglacial site so special, that even Allerød pine-apples have been found'.

We thank Bas van Geel and an anonymous reviewer for useful suggestions to improve the manuscript.

\section{Supplementary material}

To view supplementary material for this article, please visit https://doi.org/10.1017/njg.2017.4

\section{References}

Berendsen, H.J.A., Hoek, W.Z. \& Schorn, E.A., 1995. Late Weichselian and Holocene river channel changes of the rivers Rhine and Meuse in the Netherlands (Land van Maas en Waal). Paläoklimaforschung 14: 151-171.

Bohncke, S.J.P., 1993. Lateglacial environmental changes in the Netherlands: spatial and temporal patterns. Quaternary Science Reviews 12: 707-717.

Bohncke, S.J.P. \& Hoek, W.Z., 2007. Preboreal oscillations as recorded in a calcareous gyttja: different proxies and different timing. Quaternary Science Reviews 26: 1965-1974.

Bohncke, S.J.P., Vandenberghe, J. \& Huijzer, A.S., 1993. Periglacial environments during the Weichselian Lateglacial in the Maas valley, the Netherlands. Geologie en Mijnbouw 72: 193-210.

Bohncke, S.J.P., Kasse, C., Van Geel, B. \& Vandenberghe, J., 1994. Lateglacial and early Holocene environmental evolutions, Dinkel and Maas valley, the Netherlands. 4th International IGCP-253/NASP Workshop, 14-18 April 1994, the Netherlands. Excursion guide.
Bos, J.A.A., 1998. Aspects of Lateglacial to Early Holocene vegetation development in Western Europe; palynological and palaeobotanical investigations in Brabant (the Netherlands) and Hessen (Germany). PhD Thesis. Universiteit Utrecht (Utrecht), LPP Contributions Series No 10: 240 pp.

Bos, J.A.A., 2001. Lateglacial and Early Holocene vegetation history of the northern Wetterau and Amöneburger Basin (Hessen), central-west Germany. Review of Palaeobotany and Palynology 115: 177-212.

Bos, J.A.A, \& van Geel, B., 2017. Palaeoenvironmental reconstruction based on the Early Holocene Haelen sequence, near Roermond (southeastern Netherlands). Netherlands Journal of Geosciences / Geologie en Mijnbouw, this issue.

Bos, J.A.A. \& Zuidhoff, F.S., 2015. De restgeul van Well-Aijen. Een reconstructie van de vegetatieontwikkeling van het Noord-Limburgse Meusedal gedurende het Holoceen (Mesolithicum-Vroeg Romeinse tijd). ADC-rapport 3599: 92 pp.

Bos, J.A.A., Huisman, D.J., Kiden, P., Hoek, W.Z. \& van Geel, B., 2005. Early Holocene environmental change in the Kreekrak area (Zeeland, SWNetherlands): a multi-proxy analysis. Palaeogeography, Palaeoclimatology, Palaeoecology 227: 259-289.

Bos, J.A.A., Bohncke, S.J.P. \& Janssen, C.R., 2006. Lake level fluctuations and small-scale vegetation patterns during the Lateglacial in The Netherlands. Journal of Paleolimnology 35: 211-238.

Bos, J.A.A., van Geel, B., van der Plicht, J.H. \& Bohncke, S.J.P., 2007. Preboreal climate oscillations in Europe: wiggle-match dating and synthesis of Dutch high-resolution multi-proxy records. Quaternary Science Reviews 26: 19271950.

Buitenhuis, A. \& Wolfert, H.P., 1988. Geomorfologische kaart van Nederland 1:50000 en toelichting, kaartblad 46 Gennep. Stichting voor Bodemkartering, Wageningen / Rijksgeologische Dienst, Haarlem.

Cohen, K.M., Stouthamer, E., Pierik, H.J. \& Geurts, A.H., 2012. Digitaal Basisbestand Paleogeografie van de Rijn Maas Delta. Dept Fysische Geografie, Universiteit Utrecht. Digitale dataset. Available at https://easy.dans.knaw.nl/ui/ datasets/id/easy-dataset:57727.

de Mulder, E.F.J., Geluk, M.C., Ritsema, I., Westerhoff, W.E. \& Wong, T.E., 2003. De ondergrond van Nederland: Geologie van Nederland, deel 7. Drukkerij Peeters (Herent, België): 379 pp.

de Wit, M.J.M., 2008. Van regen tot Maas: grensoverschrijdend waterbeheer in droge en natte tijden. Veen Magazines (Diemen): $216 \mathrm{pp}$.

Hoek, W.Z., 1997a. Palaeogeography of Lateglacial vegetations: aspects of Lateglacial and early Holocene vegetation, abiotic landscape and climate in the Netherlands. NSG 230 Koninklijk Nederlands Aardrijkskundig Genootschap (Utrecht/Amsterdam): $128 \mathrm{pp}$.

Hoek, W.Z., 1997b. Atlas to palaeogeography of Lateglacial vegetations - maps of Lateglacial and early Holocene landscape and vegetation in the Netherlands, with an extensive review of available palynological data. NSG 231 Koninklijk Nederlands Aardrijkskundig Genootschap (Utrecht/Amsterdam): $176 \mathrm{pp}$.

Hoek, W.Z., 2000. Abiotic landscape and vegetation patterns in the Netherlands during the Weichselian Late Glacial. Geologie en Mijnbouw / Netherlands Journal of Geosciences 79: 497-509.

Hoek, W.Z., 2001. Vegetation response to the $\sim 14.7$ and $\sim 11.5$ ka cal. BP climate transitions: is vegetation lagging climate? Global and Planetary Change 30: 103-115.

Hoek, W.Z., 2008. The Last Glacial-Interglacial Transition. Episodes 31(2): 226229. 
Hoek, W.Z. \& Bohncke, S.J.P., 2002. Climatic and environmental events over the Last Termination, as recorded in the Netherlands: a review. Netherlands Journal of Geosciences / Geologie en Mijnbouw 81: 123-137.

Huisink, M., 1997. Lateglacial sedimentological and morphological changes in a lowland river in response to climatic change; the Maas, southern Netherlands. Journal of Quaternary Science 12: 209-224.

Huisink, M., 1999. Lateglacial river sediment budgets in the Maas valley, The Netherlands. Earth Surface Processes and Landforms 24: 93-109.

Huntley, B. \& Birks, H.J.B., 1983. An atlas of past and present pollen maps for Europe: 0-13,000 years ago. Cambridge University Press (Cambridge): $667 \mathrm{pp}$.

Isarin, R., Rensink, E., Ellenkamp, R. \& Heunks, E., 2015. Archeologische Verwachtingskaart Maasdal tussen Mook en Eijsden. Rijksdienst voor het Cultureel Erfgoed (Amersfoort). Available at https://archeologieinnederland.nl/bronnen-en-kaarten/verwachtingskaartmaasdal-tussen-mook-en-eijsden.

Kasse, C., 1995. Younger Dryas cooling and fluvial response (Maas River, the Netherlands) (extended abstract). Geologie en Mijnbouw 74: 251-256.

Kasse, C. \& Bohncke, S.J.P., 1991. Lateglacial and Holocene evolution of the Meuse valley. IGU Commission on Frost Action Environments, IPA Working Group on Periglacial Environments. Symposium on 'Periglacial environments in relation to climatic change', 3-6 May 1991,Vrije Universiteit, Amsterdam. Excursion guide: 91-104.

Kasse, C., Vandenberghe, J. \& Bohncke, S.J.P., 1995. Climatic change and fluvial dynamics of the Maas during the Late Weichselian and early Holocene. In: Frenzel, B., Vandenberghe, J., Kasse, C., Bohncke, S. \& Gläser, B. (eds): European river activity and climatic change during the Lateglacial and early Holocene. Paläoklimaforschung 14: 123-150.

Kasse, C., Huisink, M., Hoek, W.Z. \& Vandenberghe, J., 2000. Comment: Fluvial incision and channel downcutting as a response to Lateglacial and early Holocene climate change: the lower reach of the River Meuse (Maas), the Netherlands. Journal of Quaternary Science 15: 91-94.

Kasse, C., Hoek, W.Z., Bohncke, S.J.P., Konert, M., Weijers, J.W.H., Cassee, M.L. \& van der Zee, R.M., 2005. Late Glacial fluvial response of the Niers-Rhine (western Germany) to climate and vegetation change. Journal of Quaternary Science 20(4): 377-394.

Kasse, C., Vandenberghe, D., De Corte, F. \& Van den Haute, P., 2007. Late Weichselian fluvio-aeolian sands and coversands of the type locality Grubbenvorst (southern Netherlands): sedimentary environments, climate record and age. Journal of Quaternary Science 22: 695-708

Lowe, J.J., Rasmussen, S.O., Björck, S., Hoek, W.Z., Steffensen, J.P., Walker, M.J.C., Yu, Z.C. \& the INTIMATE group, 2008. Synchronisation of palaeoenvironmental events in the North Atlantic region during the Last Termination: a revised protocol recommended by the INTIMATE group. Quaternary Science Reviews 27: 6-17.

Miedema, $\boldsymbol{R}_{\text {., }}$ 1988. Soil formation, microstructure and physical behavior of Late Weichselian and Holocene Rhine deposits in the Netherlands. PhD Thesis. Landbouwuniversiteit (Wageningen): $339 \mathrm{pp}$.

Pons, L.J., 1957. De geologie, de bodemvorming en de waterstaatkundige ontwikkeling van het Land van Maas en Waal en een gedeelte van het Rijk van Nijmegen. Mededelingen van de Stichting voor Bodemkarting, Bodemkundige studies 3.

Pons, L.J. \& Schelling, J., 1951. De laatglaciale afzettingen van de Rijn en de Maas. Geologie en Mijnbouw 13: 293-297.
Schelling, J., 1951. Een bodemkartering van Noord-Limburg (Gemeenten Ottersum, Gennep en Bergen). Verslagen van landbouwkundige onderzoekingen 5717, Stichting voor Bodemkartering (Wageningen).

Schwan, J.C.G., 1988. The structure and genesis of Weichselian to Early Holocene aeolian sand sheets in Western Europe. Sedimentary Geology 55: 197232.

Tebbens, L.A., Veldkamp, A., Westerhoff, W. \& Kroonenberg, S.B., 1999. Fluvial incision and channel downcutting as a response to Lateglacial and early Holocene climate change: the lower reach of the river Meuse (Maas), the Netherlands. Journal of Quaternary Science 14: 59-75.

Teunissen, D., 1983. The development of the landscape of the nature reserve 'de Hamert' and its environs in the northern part of the province of Limburg, the Netherlands. Geologie en Mijnbouw 62: 569-576.

Teunissen, D., 1990. Palynologisch onderzoek in het oostelijk rivierengebied; een overzicht. Mededelingen van de afdeling Biogeologie van de discipline Biologie van de Katholieke Universiteit van Nijmegen, nr 16.

van Balen, R.T., Houtgast, R.F., van der Wateren, F.M., Vandenberghe, J. \& Bogaart, P.W., 2000. Sediment budget and tectonic evolution of the Meuse catchment in the Ardennes and the Roer Valley Rift System. Global and Planetary Change 27: 113-129.

van Balen, R.T., Houtgast, R.F. \& Cloetingh, S.A.P.L., 2005. Neotectonics of The Netherlands: a review. Quaternary Science Reviews 24(3): 439454.

van den Berg, M.W., 1996. Fluvial sequences of the Maas; a 10 Ma record of neotectonics and climate change at various time-scales. PhD Thesis. Landbouwuniversiteit, Wagningen (Wageningen): $181 \mathrm{pp}$.

Vandenberghe, J.F., Kasse, C., Bohncke, S.J.P. \& Kozarski, S., 1994. Climate related river activity at the Weichselian-Holocene transition: a comparative study of the Warta and Maas rivers. Terra Nova 6: 476-485.

van den Broek, J.M.M., \& Maarleveld, G.C., 1963. The Late-Pleistocene terrace deposits of the Meuse. Mededelingen Geologische Stichting 16: 1324.

van der Hammen, Th., 1951. Late-glacial flora and periglacial phenomena in the Netherlands. PhD Thesis. Leiden: 183 pp.

van Geel, B. \& Kolstrup, E., 1978. Tentative explanation of the Late Glacial and early Holocene climatic changes in north-western Europe. Geologie en Mijnbouw 57: 87-89.

van Geel, B., Bohncke, S.J.P. \& Dee, H., 1981. A palaeoecological study of an upper Late Glacial and Holocene sequence from 'De Borchert', the Netherlands. Review of Palaeobotany and Palynology 31: 367-448.

van Geel, B., Coope, G.R. \& van der Hammen, T., 1989. Palaeoecology and stratigraphy of the Lateglacial ype section at Usselo (the Netherlands). Review of Palaeobotany and Palynology 60: 25-130.

van Huissteden, J. \& Kasse, C., 2001. Detection of rapid climate change in the Last Glacial fluvial successions in the Netherlands. Global and Planetary Change 28: 319-339.

Westerhoff, W.E., 2008. Stratigraphy and sedimentary evolution of the lower Rhine-Meuse system during the Late-Pliocene and Early Pleistocene (southern North Sea Basin). PhD Thesis. Vrije Universiteit Amsterdam (Amsterdam): $168 \mathrm{pp}$.

Westerhoff, W.E. \& Broertjes, J.P., 1990. Excursiegids 30e Belgisch-Nederlandse palynologendagen, 4-5 0ctober 1990, Arcen. RGD, district Zuid, kantoor Nuenen: $54 \mathrm{pp}$. 
Wolfert, H.P. \& de Lange, G.W., 1990. Geomorfologische kaart van Nederland 1:50000 en toelichting, kaartblad 52 Venlo. Stichting voor Bodemkartering (Wageningen) / Rijksgeologische Dienst (Haarlem).

Zagwijn, W.H. \& van Staalduinen, C.J., 1975. Toelichting bij geologische overzichtskaarten van Nederland. Rijks Geologische Dienst (Haarlem).
Zuidhoff, F.S. \&Bos, J.A.A., 2017. Sedimentation and vegetation history of a buried Meuse terrace during the Holocene in relation to the human occupation history (Limburg, The Netherlands). Netherlands Journal of Geosciences, this issue.

Zuidhoff, F.S. \& Huizer, J., 2015. De noordelijke Maasvallei door de eeuwen heen. ADC monografie 19, 490 pp. 